TITLE:

NOTEWORTHY OCTOCORALS

COLLECTED OFF THE SOUTHWEST

COAST OF KII PENINSULA, MIDDLE

JAPAN -PART 2, TELESTACEA,

GORGONACEA AND

PENNATULACEA-

\author{
$\operatorname{AUTHOR}(\mathrm{S})$ : \\ Utinomi, Huzio
}

CITATION:

Utinomi, Huzio. NOTEWORTHY OCTOCORALS COLLECTED OFF THE SOUTHWEST COAST OF KII PENINSULA, MIDDLE JAPAN -PART 2, TELESTACEA, GORGONACEA AND

PENNATULACEA-. PUBLICATIONS OF THE SETO MARINE BIOLOGICAL LABORATORY 1961, 9(1): $197-228$

ISSUE DATE:

1961-05-30

URL:

http://hdl.handle.net/2433/174656

RIGHT: 


\title{
NOTEWORTHY OCTOCORALS COLLECTED OFF THE SOUTHWEST COAST OF KII PENINSULA, MIDDLE JAPAN
}

\author{
PART 2, Telestacea, gorgonacea and PenNatulacea ${ }^{1)}$
}

Huzio UTINOMI

Seto Marine Biological Laboratory, Sirahama

\section{With Plates VII-X and 14 Text-figures}

\section{Introduction}

The present paper continues the records or descriptions of some noteworthy octocorals found in the offshore bottom samples collected by the bull trawler "Kaiun-maru" in the outer sublittoral region off the southwest coast of Kii Peninsula, mostly from the depths of about 100-200 meters. Therefore, the octocorals herein reported, especially the gorgonaceans, are for the most part fragments or small-sized forms, larger forms being more abundantly found there in shallower waters.

Part 1, which covered the Stolonifera and Alcyonacea, appeared in this journal, Volume VIII, no. 1 (1960). This second part deals with the members of the remaining groups, Telestacea, Gorgonacea and Pennatulacea.

\section{LIST OF THE SPECIES TREATED IN THIS PAPER}

\section{Telestacea}

1. Telesto trichostemma (DANA)

2. Telesto arborea WRIGHT \& STUDER

3. Paratelesto rosea (KINOSHITA)

\section{Gorgonacea}

4. Parisis minor WRIGHT \& STUDER

5. Acalycigorgia inermis (HEDLUND)

6. Acalycigorgia irregularis KüKENTHAL \& GORZAWSKY

1) Contributions from the Seto Marine Biological Laboratory, No. 365.

Publ. Seto Mar. Biol. Lab., IX (1), 1961. (Article 11) 
7. Acanthogorgia japonica KüKENTHAL \& GoRZAwSKY

8. Discogorgia dendritica (NUTTING)

9. Muricella abnormalis NutTing

10. Muricella nitida (VERRILL)

11. Muricella magna n. sp.

12. Astrogorgia rubra Thomson \& Henderson

13. Menella indica GRAY

14. Filigella mitsukurii KINosHITA

15. Euplexaura attenuata (NuTTING)

16. Chrysogorgia rotunda KInOshita

17. Plumarella cristata KÜKENTHAL \& GORZAwSKY

18. Plumarella serta KüKEnTHAL \& GoRZAwSKY

19. Thouarella hilgendorfi (STUDER)

\section{Pennatulacea}

20. Cavernularia abesa Milne Edwards \& Haime

21. Echinoptilum macintoshi HUBRECHT

22. Sclerobelemnon burgeri (HERKLOTs)

23. Funiculina quadrangularis (PALLAS)

24. Stachyptilum dofleini BALss

25. Leioptilus fimbriatus (HERKLOTS)

26. Pteroeides breve KölLIKER

\section{TELESTACEA}

\section{Family Telestidae H. MiLNE EdwardS}

\section{Telesto trichostemma (DANA), 1846}

Gorgonia trichostemma DANA, 1846, p. 665, pl. 59, fig. 3 .

Telesto (Carijoa) trichostemma WRIGHT \& STUDER, 1889, p. 264 ; STUDER, 1889, p. 2, pl. 3, fig. 1a-b; pl. 5, fig. 1 ; pl. 6, figs. 1-2; Thomson \& Henderson, 1905, p. 319.

Telesto trichostemma Hickson, 1903, p. 481 ; LAACKMANN, 1909, p. 77 ; THOMSON \& MACKINNON, 1911, p. 692 ; KÜKENTHAL, 1911, p. 326, text-figs. 42-44, pl. 21, fig. 14 ; HiCKsoN, 1921, p. 369 ; UTiNomI, 1956a, p. 224, fig. 1.

Material. 5 fragments. Off Minabe, 100-200 m. III-1950. M. Ozaki coll.

The specimens are all fragmental, very flabby in texture and dirty white in color. They are as usual covered by an encrusting siliceous sponge (Prosuberites after HICKSON) thinly.

Records of occurrence. Widely distributed in the Indo-West Pacific: Fiji Islands (DANA), Torres Straits, 3-11 fms. (Wright \& Studer), Aru Islands (Kükenthal), Australia (Thomson \& Mackinnon), Patani, Siam (Thomson \& 
Henderson), Maldive Archipelago, 25 fms. (Hickson), Koror Island, Palau (Utinomi), Uraga Channel, mouth of Tokyo Bay, 40-200 fms. (Hickson), Miike Harbour in the Ariake Bay, Kyusyu, intertidal (Unpublished). From these records it seems to occur in shallow seas down to 200 fathoms in depth.

\section{Telesto arborea WRIGHT \& STUDER, 1889}

(Fig. 1)

Telesto (Carijoa) arborea WRIGHT \& STUDER, 1889, p. 262, pl. 39, figs. 1-1a; THOMsON \& HeNDERSON, 1906, p. 433 ; LAACKMANN, 1909, p. 88, text-fig. G, pl. IV, fig. 6.

Telesto arborea Thomson \& MACKINNON, 1911, p. 692, pl. 67, fig. 2; Thomson \& DEAN, 1931, p. 212 , pl. XI, figs. 4 and 6 .

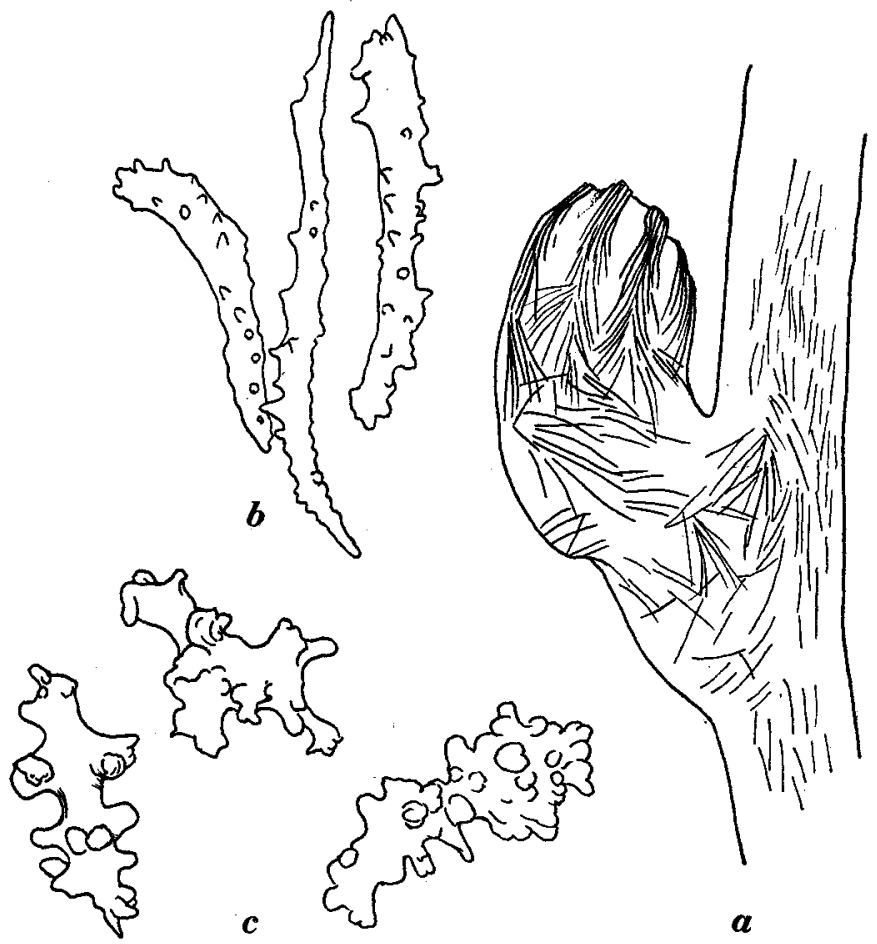

Fig. 1. Telesto arborea WRIGHT \& STUDER.

$a$, Lateral polyp; $b$, anthocodial spicules; $c$, spicules from body wall of stem.

$$
[a, \times 18 ; b-c, \times 150 .]
$$

Material. A fragment. Southwest of Minabe, $100-200 \mathrm{~m}$. III-1944. S. SaKaguchi coll.

Description. The material consists of a single stem, about $9 \mathrm{~cm}$ in length, 
showing only a trace of branching in the basal part fixed to a shell shingle.

The stem, presumably of a younger stage, is evenly slender and longitudinally ridged in 8 rows closely packed with spicules. The diameter of the stem is approximately $0.7 \mathrm{~mm}$ distally and $1.2 \mathrm{~mm}$ basally. The distal part of the stem bears only seven lateral polyps, alternately arranging at an interval of about 3-4 mm.

The lateral polyps are all cylindrical, about $3-5 \mathrm{~mm}$ long and $1.2 \mathrm{~mm}$ wide. They exhibit eight longitudinal ridges where elongate spicules are closely packed together, leaving eight naked furrows between them. These spicules are either slender warty spindles or needles, measuring about $0.18-0.4 \mathrm{~mm}$ long and $0.017-$ $0.018 \mathrm{~mm}$ wide.

The spicules of the stem wall are shorter but stouter tuberculate spindles or capstans, about $0.1-0.26 \mathrm{~mm}$ long and $0.02-0.035 \mathrm{~mm}$ wide. There is no sign of fusion between these spicules whatever.

Records of occurrence. Arafura Sea, $49 \mathrm{fms}$. (WRIGHT \& STUDER), Australia (Thomson \& Mackinnon), Maldive Archipelago, 23-25 fms. (Hickson), Zanzibar, $10 \mathrm{fms}$. (Thomson \& Henderson), Amboina and Sydney (LaAckmann), Malay Archipelagoes, down to $250 \mathrm{~m}$ in depth (Thomson \& DeAN).

\section{Paratelesto rosea (KinoshitA), 1909}

Telesto rosea Kinoshita, 1909a, p. 119; KInoshita, 1910, p. 209 (partim); KüKenthal, 1913, p. 234 (listed only).

Paratelesto rosea UTiNomi, 1958, p. 93, textfig. 2, pl. 5, figs. 2-4.

Material. 1) Many specimens. Kii-ôsima. 1940. S. SAKAgUchi coll.

2) 2 specimens. Off Minabe, $100-200 \mathrm{~m}$. III-1944. S. SaKaguchi coll.

3) 1 specimen. Mouth of Tanabe Bay, $30 \mathrm{~m}$. 26-IX-1953.

4) Fragments. Mouth of Tanabe Bay, $30 \mathrm{~m}$. 29-IV-1955. T. YaMAMOTo coll.

5) 7 specimens. Mouth of Tanabe Bay, 20-30 m. 18-IV-1957. T. Yамамото coll.

6) 4 specimens. Off Nada, Gobô. prob. $20-30 \mathrm{~m}$. (taken by lobster-net). 27IV-1958. T. YАMAмото coll.

Records of occurrence. Kasiwazima, Prov. Tosa, $80 \mathrm{fms}$. (type locality), southwest coast of Kii Peninsula (Utinomr).

\section{GORGONACEA}

\section{Suborder SCLERAXONIA}

Family Parisididae AurivilLIus

4. Parisis minor WRIGHT \& STUDER, 1889

For description see UTINOMI, 1958, p. 101. 
Material. 2 fragments. Off Minabe, $100-200 \mathrm{~m}$. III-1944. S. SAKaguHI coll. Records of occurrence. Hitherto known only from Japan: Sagami Bay, $345 \mathrm{fms}$. Wright \& Studer), Goto Islands, $160 \mathrm{~m}$ and Bonin Islands, $80 \mathrm{fms}$. (Aurivillius), Kasiwazima, Tosa Bay. (Utinomi).

Another species Parisis fruticosa VERRILL, type of the genus, has been found off Nada on April 27, 1958. In this area, this species seems to occur in inshore waters shallower than 50 meters in depth, though often recorded from deeper waters elsewhere.

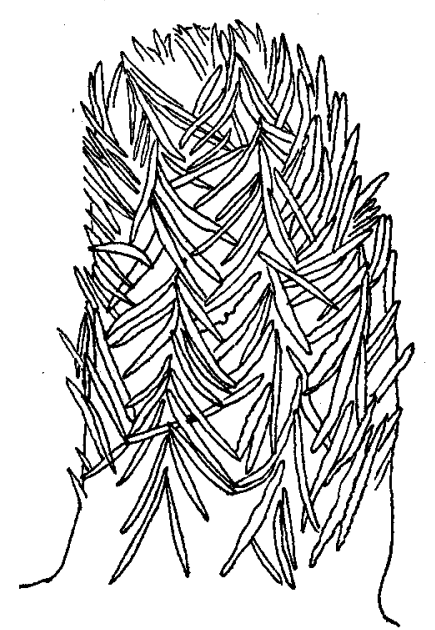

$\boldsymbol{a}$
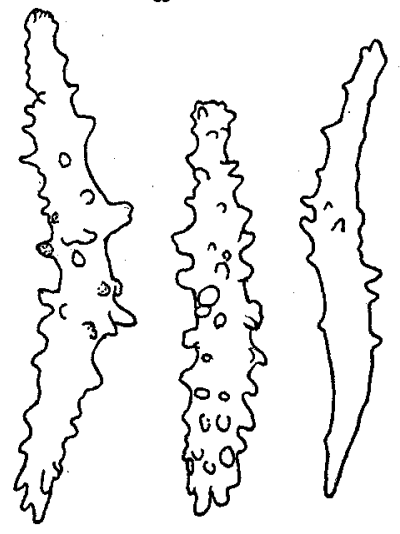

$\boldsymbol{b}$

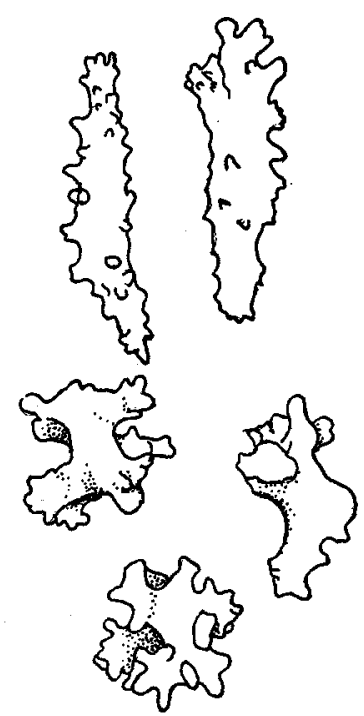

c

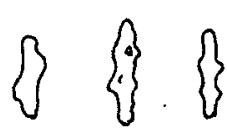

$d$

Fig. 2. Acalycigorgia inermis (HEDLund).

$a$, Details of polyp; $b$, spicules of calicular wall ; $c$, spicules of stem rind; $d$, tentacle spicules.

$[a, \times 18 ; b-d, \times 150$. $]$ 


\section{Suborder HOLAXONIA \\ Family Acanthogorgiidae GRAY \\ 5. Acalycigorgia inermis (HEDLUND), 1890}

(Fig. 2)

Acanthogorgia inermis HEDLUND, 1890, p. 6, pl. 2, figs. 1-27.

Acalycigorgia inermis KÜKENTHAL \& GoRZAwSKY, 1908, p. 49, textfig. 46, pl. 3, fig. 17; KÜKENTHAL, 1909, p. 78 ; KƯKENTHAL, 1924, p. 239, fig. 139; AURIVILlius, 1931, p. 45, pl. 2, fig. 5a-b, textfigs. 8-9; STIASNY, 1947, p. 23 (listed only); Utinomi, 1954, p. 104.

Material. One specimen. Off Minabe, 100-200 m. III-1944. S. Sakaguchi coll. Records of occurrence. Distrbuted all along the pacific coasts of southern Japan, from Sagami Bay (KüKenthal \& Gorzawsky) to Hongkong (Hedlund), rather commonly on shallower basin than on offshore basin. At living state, the extended polyps are beautifully colored purple.

\section{Acalycigorgia irregularis KüKENTHAL \& GoRZAWSKY, 1908}

(Pl. VII, fig. 1)

Acalycigorgia irregularis KüKENTHAL \& GoRZAwSKY, 1908, p. 42, textfigs. 38-40, pl. 3, fig. 15 ; KüKENTHAL, 1924, p. 238, fig. 138; STIASNy, 1947, p. 23 (listed only).

Material. One specimen. Off Tanabe Bay. II-1949. Collector unrecorded.

Description. The specimen is small, about $9 \mathrm{~cm}$ high, branched irregularly, almost in one plane.

The axis with a membranously expanded base is uniformly slender, brownish in color and issues alternately primary branches, and then a few secondary branches. The polypiferous branches are slender all throughout, about $2 \mathrm{~mm}$ in diameter.

The polyps are all small, closely disposed on all sides of the axis. They are consticted at tip and usually wider than high at a contracted state, showing a diameter of about $1 \mathrm{~mm}$. The spicules are generally smaller than those of the preceding inermis.

Record of occurrence. Hitherto known only from the type locality (Sagami Bay).

7. Acanthogorgia japonica KÜKENTHAL \& GORZAWSKY, 1908

$$
\text { (Pl. VII, fig. 2) }
$$

Acanthogorgia japonica KüKENThal \& GoRzAWSKY, 1908, p. 53, textfigs. 47-50, pl. 3, fig. 18 ; KÜKENTHAL, 1924, p. 249, fig. 143.

Paracanthogorgia japonica STIASNY, 1947, p. 59 (listed only). 
Material. 1) A fragment. Off Minabe. II-1949. Collector unrecorded.

2) One specimen. Off Minabe. 4-V-1958. K. Mirasi coll.

Description. As shown by a color photograph of a complete colony obtained in Ise Bay (UTINOMI, 1956, pl. 9, fig. 7), the colony is rather ramose, not branching in one plane and dirty yellowish brown in color. The branches arise approximately at right angles and bear many large polyps on all sides. They are about $7-12 \mathrm{~mm}$ in diameter, when the polyps around the axis are combined together. Each polyp is about $3 \mathrm{~mm}$ high and $1.5 \mathrm{~mm}$ wide. The axis is robust, horny and dark brown. Details of the spiculation agree well with the original description.

Record of occurrence. Hitherto known only from the type locality (Sagami Bay, 80-250 m).

\section{Family Paramuriceidae BAYER \\ 8. Discogorgia dendritica (NuTTING), 1910}

(Fig. 3 ; pl. VII, fig. 4)

Placogorgia dendritica NuTTING, 1910a, p. 79, pl. 12, figs. 1-1a, pl. 22, fig. 6.

Discogorgia dendritica KÜKENTHAL, 1924, p. 214 ; BAYER, 1956, p. F 203, fig. 2a-d.

Material. 2 specimens. $23 \mathrm{~km}$ west of Setozaki, $80-150 \mathrm{~m}$. 28-XI-1957. E. Harada coll.

Description. Both specimens, $9 \mathrm{~cm}$ and $12 \mathrm{~cm}$ respectively in height, are attached by a membranous base to a broken shell, and loosely branched in one plane. The colony is generally pale brown, but the polyps appear purplish brown. The lower part of the main stem and lower branches lacks the calicles, and about $2 \mathrm{~mm}$ in diameter.

The calicles are closely arranged in four longitudinal rows, about $2 \mathrm{~mm}$ apart, though somewhat twisted here and there.

The individual calicles are rather high cones, averaging about $1.5 \mathrm{~mm}$ high and $1.5-1.8 \mathrm{~mm}$ in basal diameter. Their walls appear qnite smooth at a glance, but they are really ornamented with small, thorn-scales bearing jagged margins or foliaceous projections, compactly packed together.

The retractile polys rest above the calicles, about $0.5 \mathrm{~mm}$ high and $1.2 \mathrm{~mm}$ wide, are armed with about 4 or 5 transverse rows of small collaret spicules, 8 points of larger spicules, and each a small intermediate spicule between the points.

In the rind of the basal part of the stem there found no thorn-scales as seen in the calicles and upper rind.

Details of spicules and their measurements (in $\mathrm{mm}$ ) are:

Calicles and upper rind-thorn-scales of irregular shape, with jagged margins and often foliaceous wide projections. $0.32 \times 0.14,0.35 \times 0.12,0.35 \times 0.03$, $0.45 \times 0.3$

Sterile basal rind and axial sheath-mostly thorny spindles and derivatives. 
$0.038 \times 0.035,0.12 \times 0.05,0.26 \times 0.05,0.23 \times 0.17,0.35 \times 0.07$

Points and collarets-feebly warted spindles. $0.3 \times 0.03,0.62 \times 0.08,0.9 \times 0.09$

Tentacles-flattened rods. $0.17 \times 0.01$

Record of occurrence. Hitherto known only from the type locality (Kwandang Bay entrance $80 \mathrm{~m}$ and Buton Island 75-94 m, Malay Archipelago).

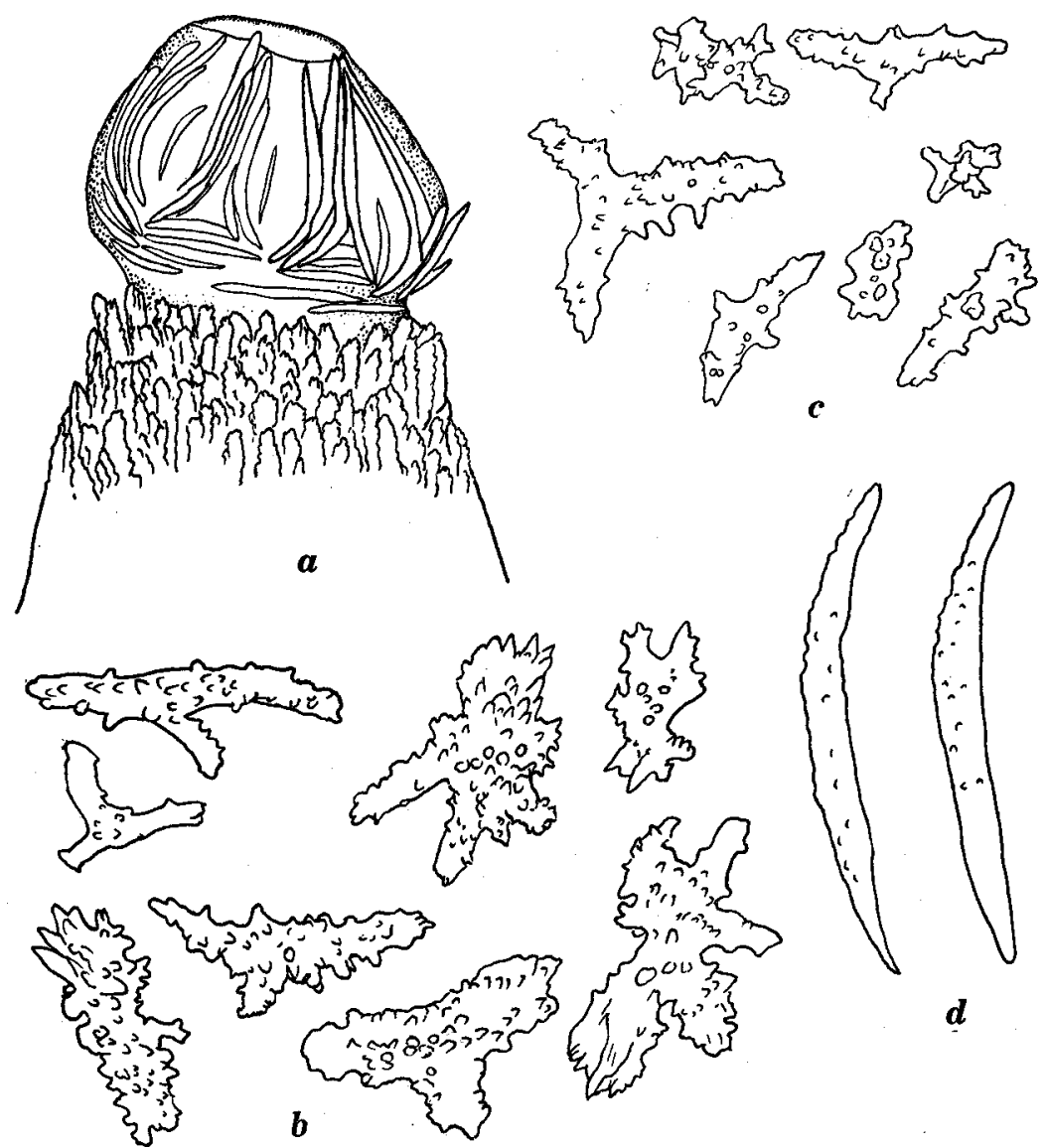

Fig. 3. Discogorgia dendritica (NuTTING).

$a$, Tip of calicle with extended polyp; $b$, thorny scales from stem rind and calicular ${ }^{-}$wall ; $c$, spicules of various shape from sterile basal part of stem rind ; $d$, anthocodial spicules. $[a, \times 33 ; b-d, \times 80$. $]$

9. Muricella abnormalis NuTTING, 1912

(Fig 4 ; Pl. VII, fig. 3)

Muricella abnormalis NutTING, 1912, p. 79, pl. 11, figs. 3-3a, pl. 20, fig. 6; KükENTHAL, 1924, p. 174; BAYER, 1956, p. F206, fig. 149 (1). 
Material. 1) One broken specimen. Off Minabe, 100-200 m. III-1944. S. SAKAGUCHI coll.

2) One specimen. Off Tanabe Bay. III-1949. Collector unrecorded.

Description. Both specimens are scantily branched in one plane, with a slightly expanded base. They are $6 \mathrm{~cm}$ long and $12 \mathrm{~cm}$ long respectively. The axis is yellowish brown, rather stout, though slender in branches of a smaller colony.

The cortex is generally thin all throughout and the calicles are scattered on all sides of the stem and branches. The individual calicles vary in size, but a

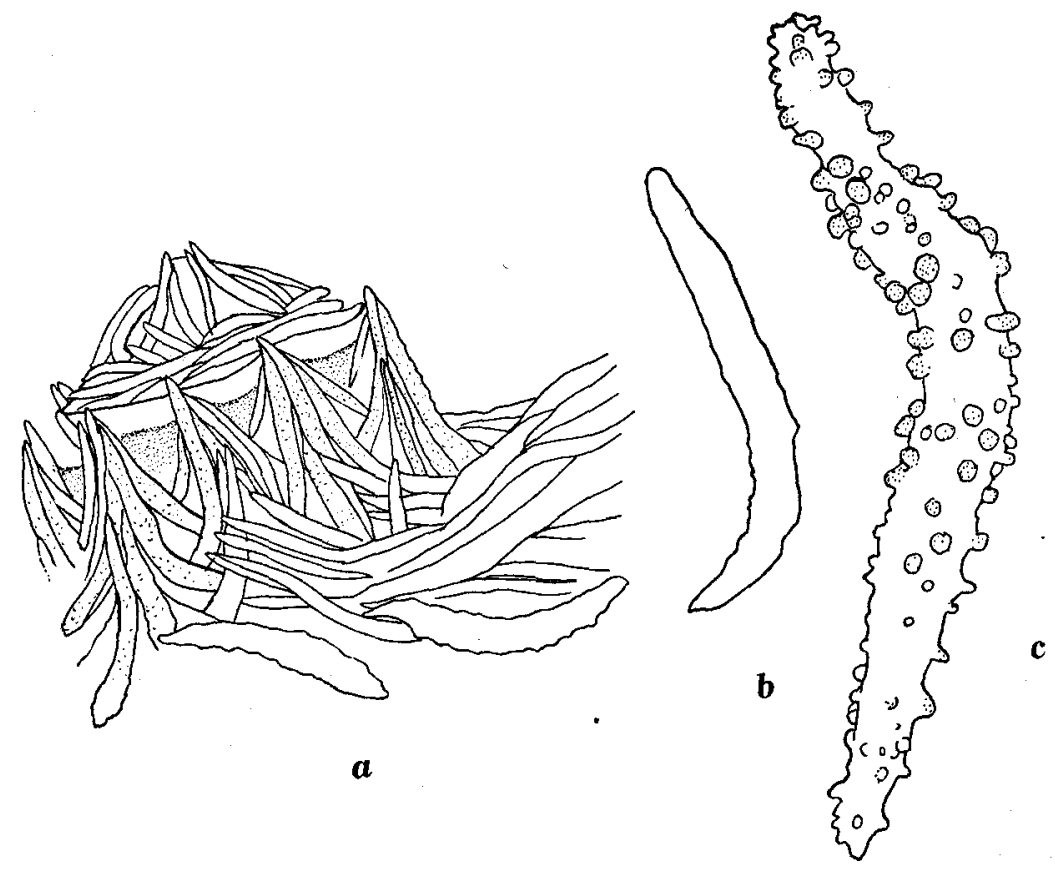

Fig. 4. Muricella abnormalis NuTTING.

$a$, Details of polyp; $b$, anthocodial spicule; $c$, calicular spicule.

$[a, \times 33 ; b-c, \times 80$. $]$

typical one is a low truncated cone, about $2 \mathrm{~mm}$ in height and so in diameter. Their walls consist of eight triangles which stand vertically above the spicules of the coenenchyma. Each of the triangles is composed of about 8 spindles converging towards the margin of the calicle and slightly projecting above the upper margin : between them there is a wide naked area above.

The polyps, when partially extended or retracted, are rather wider than high and armed with three transverse rows of collaret spindles and eight points each of which is formed of a pair of spindles. Their measurements (in $\mathrm{mm}$ ) are : 
Calicle and cortex-tuberculate spindles. $0.55 \times 0.08,0.77 \times 0.11,0.88 \times 0.11$, $1.0 \times 0.16$

Collarets-nearly smooth spindles. $0.22 \times 0.02,0.44 \times 0.05,0.55 \times 0.06$

Points-nearly smooth spindles. $0.2 \times 0.02,0.4 \times 0.05$

Record of occurrence. Hitherto known only from the type locality (Osezaki, Suruga Bay, Japan, 108 fms.).

\section{Muricella nitida (VERRILL), 1868}

(Fig. 5 ; Pl. VIII, fig. 5)

Muricea nitida VERRILI, 1868, p. 412.

Muricella nitida VerRILl, 1869, p. 450 ; WrIGHT \& STUder, 1889, p. 127; Germanos, 1896, p. 181, pl. 10, fig. 4 ; THOMSON \& HENDERSON, 1905, p. 302; THOMSON \& StMPSON, 1909, p. 245 (no new record); KÜKENTHAL, 1924, p. 172, fig. 112.

Material. One specimen. Off Minabe, 100-200 m. III-1944. S. Sakaguchi coll.

Description. The specimen consists of the basal part of a colony, about $57 \mathrm{~mm}$ in length, with two branches ( $40 \mathrm{~mm}$ long and $65 \mathrm{~mm}$ long respectively) arising at right angles from one side of the stem. Each of the two branches bears one branchlet, and they spread in one plane.

The calicles are mostly placed laterally, alternate in position at distances of about 1-3 $\mathrm{mm}$; some of them are sometimes distorted somewhat obliquely to the plane of branching. The individual calicles are usually placed perpendicularly and large, fairly cylindrical in form, about $1.5-2 \mathrm{~mm}$ high and $1.2-18 \mathrm{~mm}$ in basal diameter. Their walls are filled with red spicules vertically disposed, indistinctly converging into eight point at their tip.

The polyps, when extended, are generally longer than wide and armed with eight points forming of 2 or 3 pairs of white spicules; the collarets at base, however, seem to be indistinct, though some smaller spicules may be obliquely disposed below.

The cortex is rather thick and closely packed longitudinally with stout tuberculate spindles; those on the surface layer are much larger than those of the calicles, bright red in color, while those of the deeper layer are smaller and pink in color. The axis is horny, flexible and yellowish brown.

The measurements of spicules (in $\mathrm{mm}$ ) are:

Stem cortex-tuberculate spindles, carmin-red in outer layer and pink in deeper layer. $1.2 \times 0.3,2 \times 0.35$

Calicles-tuberculate spindles, carmin-red. $0.5 \times 0.07,0.7 \times 0.07,0.8 \times 0.1,1.0$ $\times 0.12$

Points-tuberculate spindles narrowing downwards, yellowish or pure white. $0.6 \times 0.06,0.7 \times 0.07,0.8 \times 0.1$

Tentacles-curved rods, colorless. $0.12-0.15$ long 
Records of occurrence. Ebon Island in the Central Pacific (type locality); Sagami Bay, 345 fms., Japan (Wright \& Studer); Ternate Inland, Malay Archipelago (Germanos): Ceylon Seas (Thomson \& Henderson).

Remarks. As to the coloration of Muricella nitida (VERRILL), the present specimen differs somewhat from the notes given by earlier authors, viz. the calicles and coenenchyma are reported as purplish red (VerRILL), coral red (Wright \& Studer: Thomson \& Henderson) or yellowish red (Germanos).

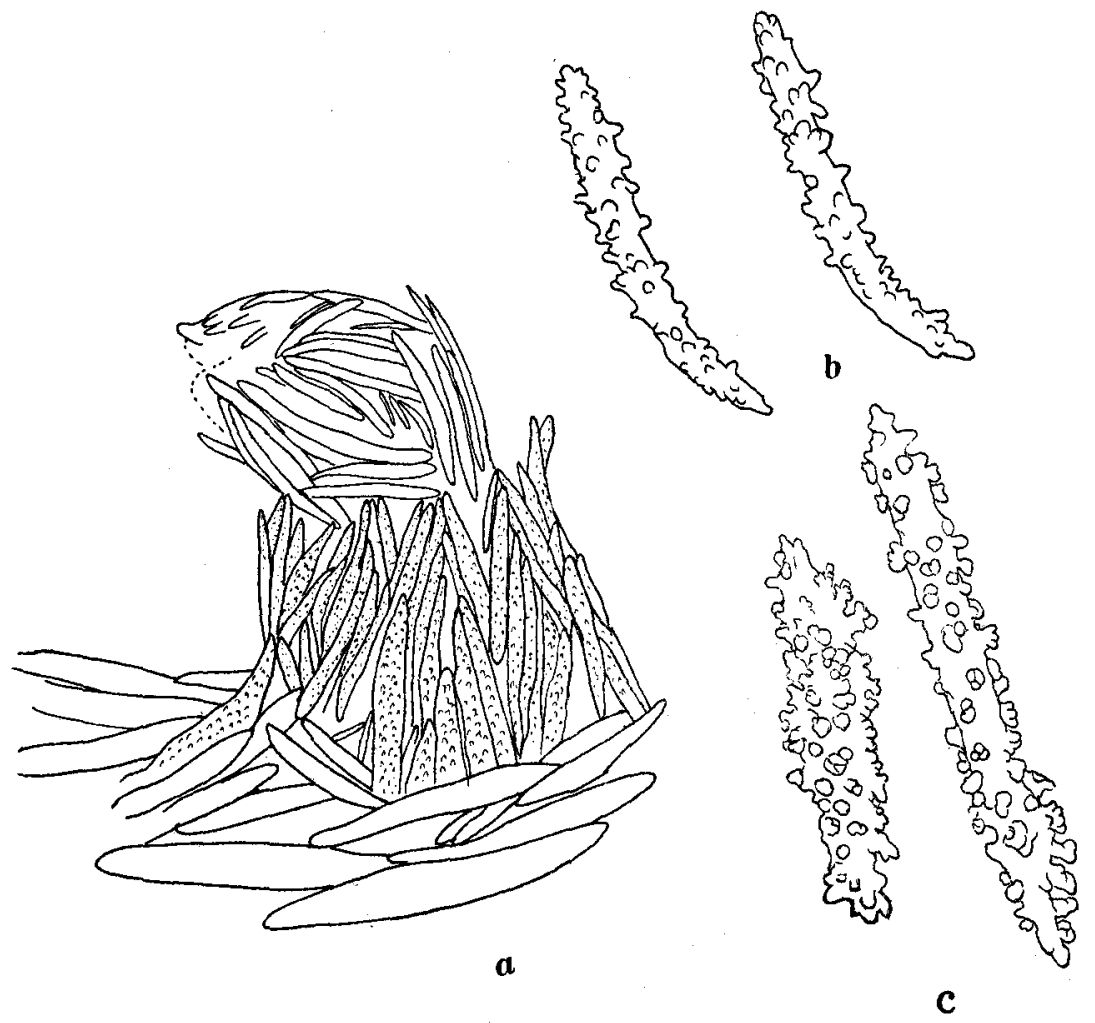

Fig. 5. Muricella nitida (VERRILL).

$a$, Details of calicle and extended polyp ; $b$, anthocodial spicules ; $c$, calicular spicules. $[a, \times 18 ; b-c, \times 80$. $]$

However, color is not always a reliable feature since it may vary within the species, sometimes due to longterm preservation, but is a useful secondary character.

11. Muricella magna $\mathrm{n}$. sp.

(Fig. 6; Pl. VIII, figs. 6-7) 
Material. One specimen (SMBL Type 185). Off Minabe, 100-200 m. III-1944. S. SaKaGuchi coll.

Description. This new species is represented by a beautiful nearly unbranched colony, light purplish red in color.

The colony, about $10 \mathrm{~cm}$ in total height, is nearly unbranched, bearing only three short branchlets near the distal part, about $6 \mathrm{~mm}, 7 \mathrm{~mm}$ and $25 \mathrm{~mm}$ respec-

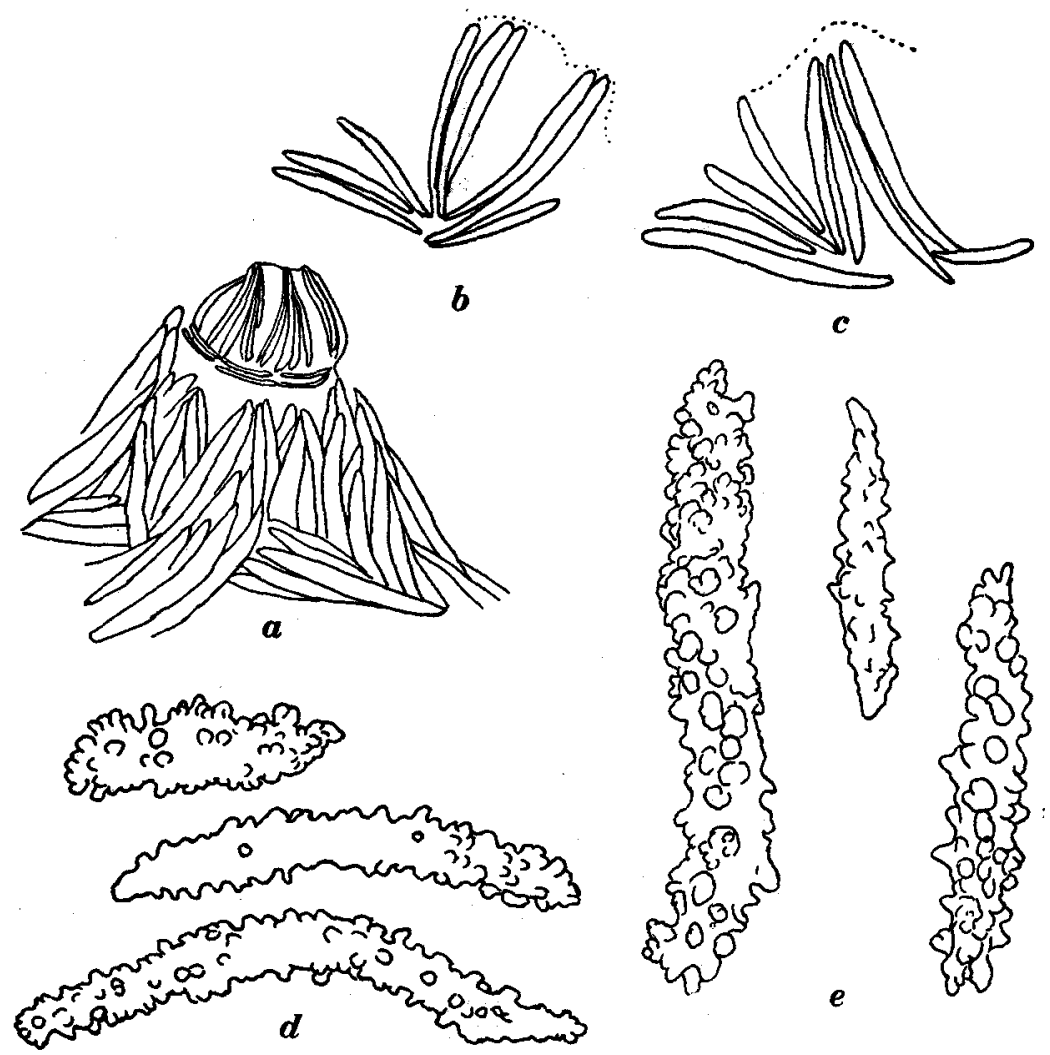

Fig. 6. Muricella magna, n. sp.

$a$, Details of polyp and calicle; $b-c$, arrangement of anthocodial spicules ; $d$, anthocodial spicules; $e$, calicular spicules.

$[a, \times 12 ; \mathrm{b}, \times 25 ; c, \times 33 ; \mathrm{d}-\mathrm{e}, \times 80$.

tively in length. The base of the main stem is expanded with a spread of about $1 \mathrm{~cm}$ across. For a distance of about $1 \mathrm{~cm}$ just above the basal disk, the stem is cylindrical, with a diamer of about $4 \mathrm{~mm}$ and devoid of calicles. In the remaining part of the stem and branchlets, the coenenchyma is flattened in the plane of branching, and their terminal ends are thickened with 3 calicles.

The coenenchyma is fairly thick and compactly filled with light purplish red 
tuberculate spindles. The calicles are irregularly distributed on all sides of the coenenchyma, usually $2 \mathrm{~mm}$ apart. The individual calicles are quite large, craterlike in form, with a round opening, about $1.5 \mathrm{~mm}$ in height and $3 \mathrm{~mm}$ in diameter at tip. Their walls are gradually sloped around and filled with spindles similar to those of the coenenchyma, distinctly converging into eight points at tip.

The polyp body is armed with vertical spindles, forming an eight-pointed prominent operculum. The collaret is formed of only two circlets of spindles which are obliquely or transversely disposed below the operculum. These polypal spicules are heavily tuberculate spindles bluntly ended and colored light purplish red like those of the calicles. The retractile neck portion of the polyps is also furnished with a number of pinkish rodlets.

The axis is rather robust, horny, brown in color, and $1 \mathrm{~cm}$ in diameter at the end of the branchlets.

Measurements of spicules (in $\mathrm{mm}$ ) are:

Calicles-tuberculate spindles, roundly ended, light purplish red. $0.5 \times 0.06$, $0.7 \times 0.2,0.8 \times 0.1,0.8 \times 0.1,1.35 \times 0.3$

Points-tuberculate spindles, curved and roundly ended, light purplish red. $0.18 \times 0.035,0.26 \times 0.05,0.35 \times 0.06,0.4 \times 0.07$

Tentacle--curved rod, colorless. $0.1-0.2$ long

Neck portion of polyp-slender rodlets or spindles, pinkish. $0.07 \times 0.03,0.1 \times$ $0.01,0.17 \times 0.02$

Remarks. The present specimen is apparently related to Muricella rubra ThOMson and $M$. perramosa RidLey in coloration, but differs from them in the scanty branching, the polypal arrangement and the thick flattened coenenchyma.

\section{Astrogorgia rubra Thomson \& Henderson, 1906}

(Fig. 7 ; Pl. VIII, fig. 8)

Astrogorgia rubra Thomson \& Henderson, 1906, p. 69, pl. 5, fig. 10; KüKenthal, 1924, p. 235 , fig. 137.

? Callistephanus koreni Thomson \& HeNderson, 1906, p. 79.

Material. A portion of a reddish colony. Off Minabe, 100-200 m. III-1944. S. Sakaguchi coll.

Description. The specimen is represented only by a part of a beautiful coral red colony, about $4 \mathrm{~cm}$ long, missing both ends. Superficially it resembles Callistephanus (=Swiftia) koreni WRIGHT \& STUDER of the Paramuriceidae or Nicellaspecies of the Ellisellidae, but may be referable to Astrogorgia rubra THomson \& HeNDERSON, previously known only from the type locality.

The coenenchyma is uniformly coral red in color, granular on surface and fairly thick. The stem is somewhat flattened and the verrucae are arranged alternately on lateral sides, the distance between two verrucae on the same side 
being about $2-3 \mathrm{~mm}$, but some of the verrucae are somewhat turned to the other sides. The diameter of the stem where the verrucae are absent is about $1.5 \mathrm{~mm}$.

The verrucae are dome-shaped, about $1.3-2 \mathrm{~mm}$ across at apex and about $1 \mathrm{~mm}$ in height. Their apical margin is marked by eight obtuse points.

The coenenchyma is fairly thick and its surface is thickly covered by small warty spindles or clubs, about $0.09 \times 0.05 \mathrm{~mm}$, perpendicularly to the surface, giving the surface a granular appearance. The inner spicules arranged longitudinally are rather longer warty spicules, or sometimes club-like gradually
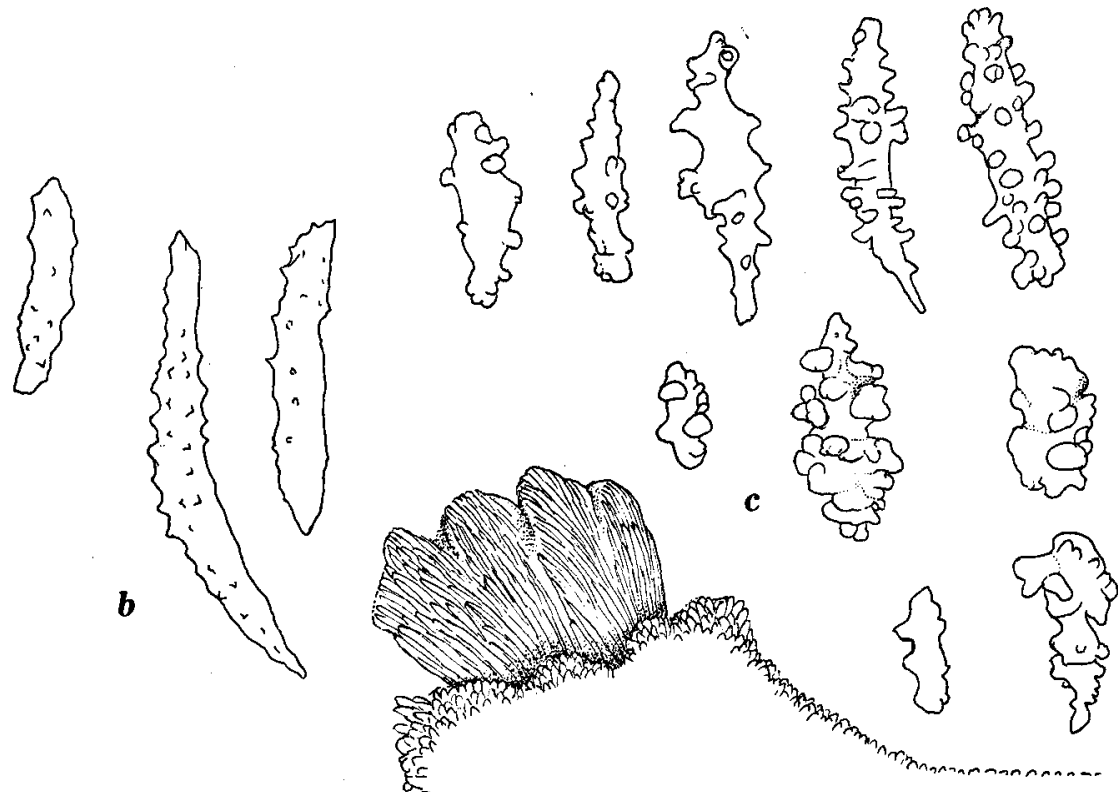

$\boldsymbol{a}$

Fig. 7. Astrogorgia rubra Thomson \& Henderson.

$a$, Details of polyp extended above calicle ; $b$, anthocodial spicules ; $c$, coenenchymal spicules.

$$
[a, \times 27 ; \mathrm{b}-\mathrm{c}, \times 140 .]
$$

tapering to one end. These spicules are all coral red and measure in $\mathrm{mm}$ :

$$
0.07 \times 0.02,0.12 \times 0.05,0.16 \times 0.035,0.18 \times 0.035,0.19 \times 0.07
$$

The polyps are completely retractile and their tip, when the tentacles are wholly withdrawn, is marked by eight rounded points like the verrucae. The anthocodial spicules are closely crowded longitudinally and light red with some grayish yellow thorny spindles, as measuring about $0.2-0.25 \mathrm{~mm}$ in length and $0.035 \mathrm{~mm}$ in width.

The axis is apparently horny, brown and about $0.5 \mathrm{~mm}$ in diameter. 
Record of occurrence. Hitherto known only from the Indian Ocean $\left(6^{\circ} 55^{\prime} 6^{\prime \prime} \mathrm{N}\right.$, $72^{\circ} 55^{\prime} \mathrm{E}, 210$ fms.).

Remraks. The genus Astrogorgia was established by Verrill (1868, p. 413; 1869, p. 43) for a unique species Muricea sinensis VerRILl (1865, p. 187, pl. 5, figs. 5-5a) from Hongkong. According to VERRILL's original and emended descriptions, the verrucae of the type species sinensis are scattered on all sides and the coenenchyma is granular on surface and deep red in color. In the second species rubra, however, the verrucae are said to be disposed in a regularly alternate manner and on larger branches they are almost opposite and the spiral twisting of the axis makes it appear as if the verrucae occurred on all the four sides; the spicules, not figured by them, are said to be all of a pink color, diverse in shape.

In all probability these specimens seem to represent a single species, when any more complete specimens would be found in the future. Furthermore, it is necessary to re-examine the type specimens of both species of Astrogorgia to reappraise their position in respect to its affinity with the related genus Swiftia Duchassainig \& Michelottr.

\section{Menella indica Gray, 1870}

(Fig. 8; PI. VIII, flg. 9)

Menella indica GraY, 1870a. p. 407 ; NUTtING, 1912, p. 86 ; KüKeNTHAL, 1924, p. 184 ; ÚTINOMI, 1958, p. 105.

Echinomuricea? sp. UTINOMI \& HARADA, 1958, p. 388 (listed only),

Material. One specimen. $23 \mathrm{~km}$ west of Setozaki, $80-150 \mathrm{~m}$. 28-XI-1957. E. HARADA coll.

Description. The specimen is represented by a very long filiform colony, $50 \mathrm{~cm}$ in total length, only giving off a shorter simple branch, $11 \mathrm{~cm}$ long, at a right angle in the middle. There is no expanded base which occurs in the related species Menella rubescens NuTTING.

The stem and branch are very slender, flexible, totally filiform and bluntly pointed at the ends. The diameter of the stem is the widest in the middle where a single branch is given off, namely $1.1 \mathrm{~mm}$, and gradually decreases distally where it is only $0.7 \mathrm{~mm}$. The diameter of the branch is likewise $0.7 \mathrm{~mm}$.

The color of the colony is pale brown. The axis is wolly horny, very flexble, about $0.7 \mathrm{~mm}$ in diameter in the middle and almost black.

The polyps are irregularly scattered on all sides, and deeply sunken into their cavities usually opened in the center of low verrucae and usually lengthened along the axis.

Each of the verrucal cavities is about $1 \mathrm{~mm}$ in long diameter and about $0.5 \mathrm{~mm}$ deep, and they are about $1-2 \mathrm{~mm}$ apart.

The coenenchyma, including the verrucal swellings, is evenly spiculose on 
surface and moderately thick. Their spicules are mostly of the Echinomuricea-type, namely thorny scales with a prominent projecing smooth spike and a few thorny basal processes, which are narrower than those of $M$. rubescens Nutring,

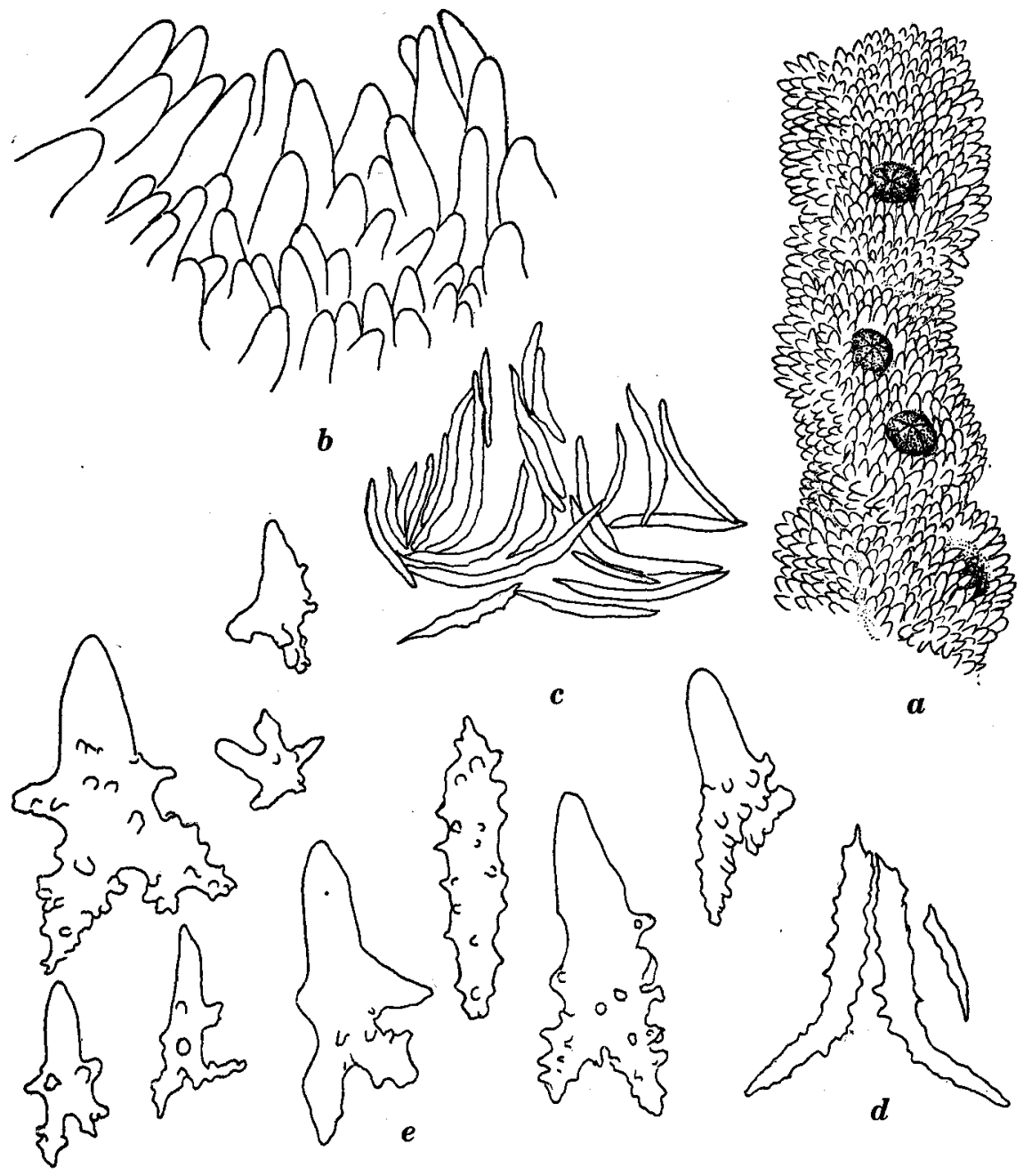

Fig. 8. Menella indica GRAY.

$a$, Part of stem, with 4 polyps sunken into calicular cavities; $b$, details of a part of calicular margins ; $c$, arrangement of anthocodial spicules; $d$, a pair of point spicules; $e$, coenenchymal spicules.

$[a, \times 18 ; b-c, \times 80 ; d-\mathrm{e}, \times 150$.

as figured by NutTing (1910a, pl. 22, fig. 13) and BAyer (1959, p. 56, fig. 1A) and those of Echinomuricea peterseni HEDLUND, as figured by HEDLUNd (1890, pl. 3) and Aurivillius (1931, p. 173, fig. 33). Between these thorny scales, larger thorny 
spindles are sporadically interspersed, filling up the intervening spaces in the deeper layer. However, there is no lobated scales basally.

The polyps are wholly retractile and all sunken deeply below the verrucal margins. The operculum consists of eight converging points and 2-3 collaret rows of slender spicules.

Measurement of these spicules (in $\mathrm{mm}$ ) are :

Verrucal and coenenchymal thorny scales. $0.16 \times 0.04,0.18 \times 0.16,0.2 \times 0.18$, $0.21 \times 0.13$

Interspersing coenenchymal thorny spindles. $0.23 \times 0.03,0.3 \times 0.05,0.33 \times 0.07$, $0.33 \times 0.08$

Anthocodial, slightly thorny or smooth, slender spindles. $0.11 \times 0.01,0.13 \times$ $0.018,0.16 \times 0.016,0.19 \times 0.02,0.2 \times 0.16$

Tentacle and pinnule spicules. $0.05-0.08$ long

Records of occurrence. Back Bay, Bombay, west coast of India (type locality); 2.6 miles off Osezaki Light, Suruga Bay, Japan, 57 fms. (Nutring); Tosa Bay, Japan (UTINOMI).

Remarks. In a review of the genus Placogorgia STUDER, BAYER (1959 a) generically distinguished Menella from Echinomuricea by the shape of the calicular thorny scales, based on the examination of spicules of two species, Menella rubescens NutTing and Echinomuricea indomalaccensis Ridley. Among the three species described by NutTing (1908 and 1910a), M. grandiflora from Hawaiian Islands is clearly a member of the stoloniferan genus Clavularia (cf. BAYER, 1952, p. 129). On the other hand, M. rubescens from Malay Archipelago seemingly approaches to Echinomuricea and $M$. grayi from Malay Archipelago approaches to Muriceides rather than to Menella indica in respect to their spiculation and mode of life (or growth form of the colony).

In comparison with Echinomuricea-speces, Menella indica, type of the genus, is unbranched or only scantily branched, with thick coenenchyma. Calicles are very low, elliptical in cross section, thickly covered by thorny scales similar to those of the surrounding cortex which are composed of a single broad smooth projecting spike and a few thorny basal branches. Polyps, when retracted, are deeply sunken below calicular margins.

\section{Filigella mitsukurii KInoshITA, 1909}

(Figs. 9 and 10 ; P1. IX, figs. 10-11)

Filigella mitsukurii KINOSHITA, 1909b, p. 1, pl. 1, fig. 1 and pl. 2, figs. 7-9 ; AURIVILLIUs, 1931, p. 129, textfig. 25, pl. 3, figs. 3-4; BAYER, 1956, p. F206, fig. 148 (3); UTINOMI \& HARADA, 1958 , p. 388 (listed only).

Elasmogorgia mitsukurii KÜKENTHAL, 1924, p. 149, fig. 104.

? Elasmogorgia filiformis NuTTING, 1912, p. 85. 
Material. 5 unbranched and scantily branched specimens. Sta. 1, $23 \mathrm{~km}$ west of Setozaki, $120 \mathrm{~m}$. Bottom : pure sand. 8-XII-1957. E. HARAda coll.

Description. This is also a very slender filiform gorgonid, not forming any ordinary attachment disk.

The unbranched forms measure $20 \mathrm{~cm}, 30 \mathrm{~cm}, 31 \mathrm{~cm}$ and $38 \mathrm{~cm}$ in length respectively. The bifurcate form is likewise a single whiplike stem, about $17 \mathrm{~cm}$ long, with a longer branch, about $22 \mathrm{~cm}$ long, arising near its base broken off.

In all these specimens, both the ends are slightly swollen and bluntly pointed like an arrow-head (Fig. 9, $a-d$ ). In the presumably lower part, the stem measures about $1 \mathrm{~mm}$ in diameter, but in the remaining parts it is less than $1 \mathrm{~mm}$ in diameter all throughout, mostly $0.5 \mathrm{~mm}$. The color is dirty white.

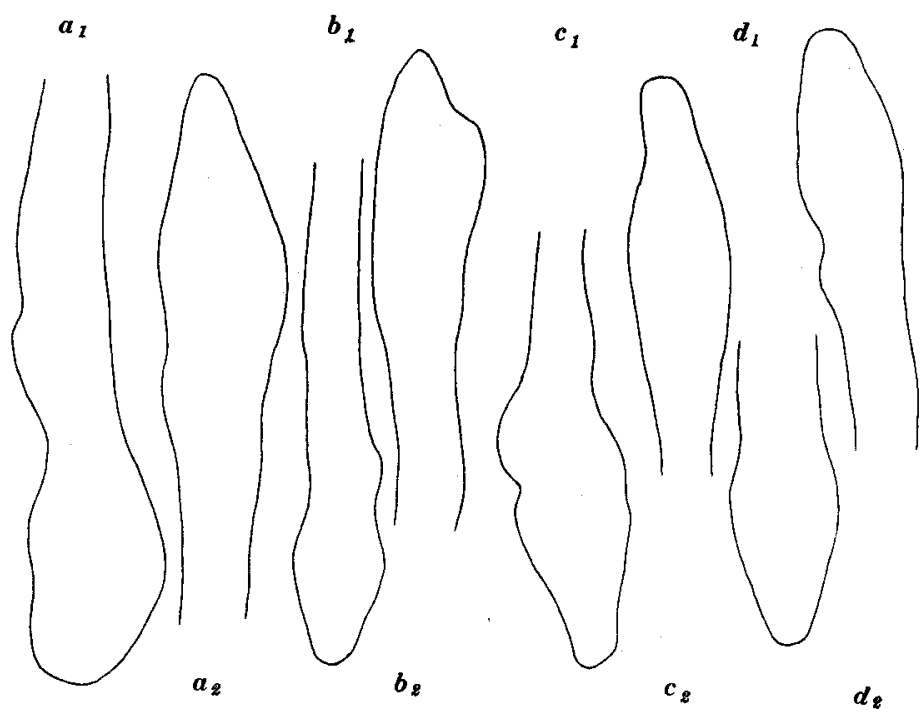

Fig. 9. Filigella mitsukurii KINOSHITA.

Outline of both ends of four colonies $(a-d)$. [X12.]

The verrucae, which are low cones when viewed from sides, are scattered on all sides, but tend to be lateral and alternate. They are about $0.5-2 \mathrm{~mm}$ apart, averaging $1 \mathrm{~mm}$. The axis is very flexible, about $0.25 \mathrm{~mm}$ in diameter and yellowish brown.

The coenenchyma is thin and covered with fusiform spicules about $0.2-0.3 \mathrm{~mm}$ long. These spicules are generally arranged longitudinally, but around the orifice of the verrucae somewhat radially, not in chevrons.

These coenenchymal spicules are somewhat larger in the surface layer than in the deeper layer, but similarly all short tuberculate spindles bluntly ended, 
with smooth or slightly roughened warts. They measure in $\mathrm{mm}$ as follows :

$0.13 \times 0.033,0.19 \times 0.05,0.25 \times 0,07,0.3 \times 0.08,0.33 \times 0.082$

The operculum of the anthocodiae consists of eight points longitudinally disposed and 2 or 3 transverse rows of collarets. These are slightly thorny

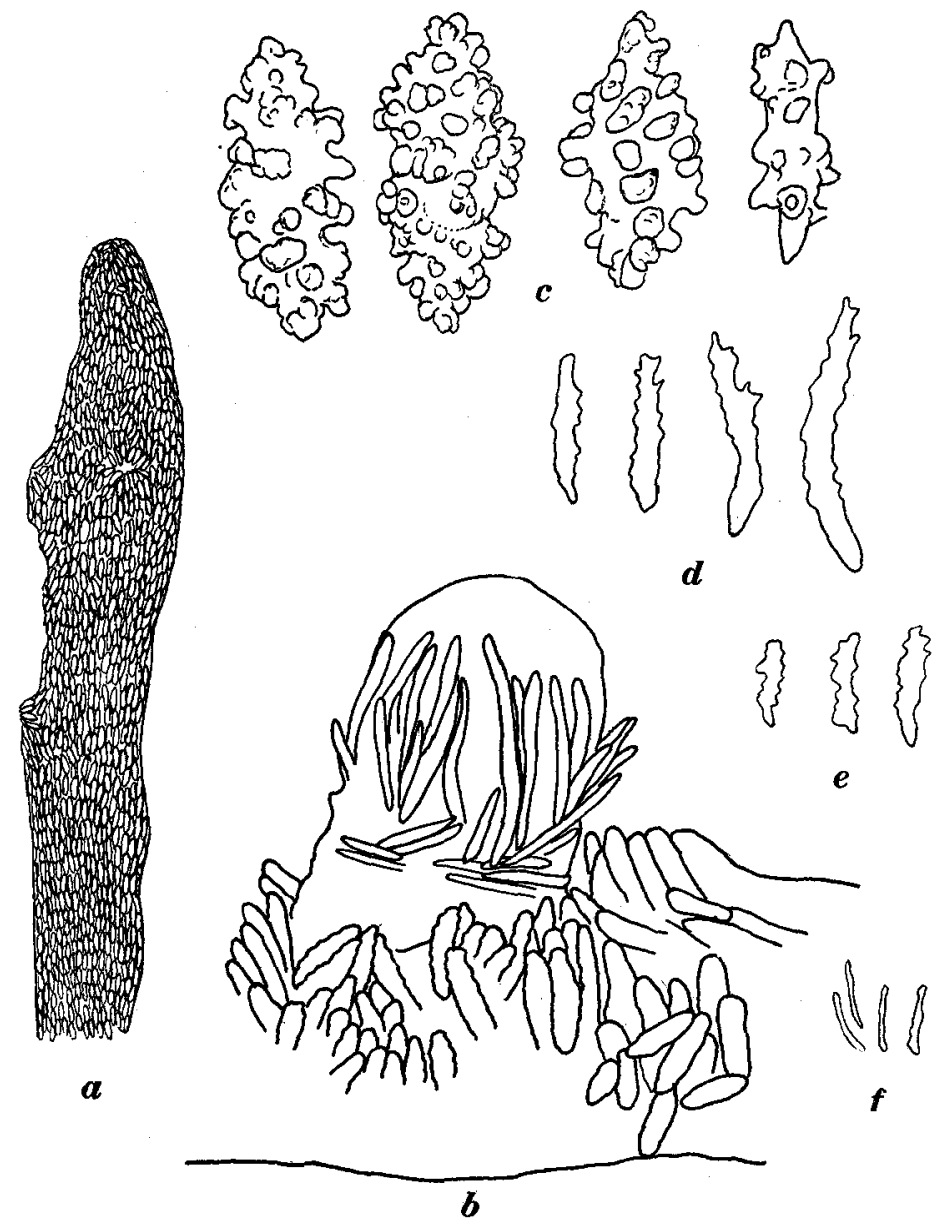

Fig. 10. Filigella mitsukurii Kinoshita.

$a$, End of colony; $b$, details of polyp partially extended out of calicle;

$c$, coenenchymal spicules; $d$, anthocodial spicules; $e$, tentacle spicules;

$f$. pinnule spicules.

$[a, \times 12 ; \mathrm{b}, \times 67 ; c-f, \times 97$.

spindles and measure in $\mathrm{mm}$ as follows:

$0.16 \times 0.02,0.19 \times 0.03,0.21 \times 0.025,0.25 \times 0.032$

Tentacle spicules are all flattened rods, as measuring in $\mathrm{mm}$ :

$0.082 \times 0.016,0.114 \times 0.032$ 
Pinnule spicules are slender rodlets, about $0.033-0.082 \mathrm{~mm}$ long.

Records of occurrence. South of Jogashima (=Zyôgasima), Sagami Bay, $70 \mathrm{fms}$. (type locality), Sagami Bay $400-450 \mathrm{~m}$ and west of Kyusyu $160-200 \mathrm{~m}$ (Aurivillius).

Remarks. As we have seen, most of the genus Filigella or Elasmogorgia and also Filigorgia ${ }^{1}$ (STIASNY, (1939, p. 301) are unbranched or scantily branched, filiform gorgonid, usually lacking the ordinary basal disk like the preceding Menella. As suggested originally by GRAY (1868, p. 443) and by KinoshitA (1909b, p, 1) and later by Aurivillius (1931, pp. 126-143), the genus Filigella, with which Elasmogorgia are synonymous, may be designated as follows:

Colony filiform, simple or scantily branched, free or fixed according to the bottom nature of its habitat; distal end slightly swollen and bluntly pointed; proximal end rounded and either free or with a small attachment disk; axis horny, very flexible; coenenchyma thin, formed of small colorless warty spindles; calicles only low mounds irregularly or alternately disposed on coenenchyma, their spiculation not specialized.

Recently BAYER (1958, p. 50;1959 b, p. 17, for Filigella gracilis) synonymized the two genera Filigella GrAY and Elasmogorgia WRIGHT \& STUder with the West Atlantic genus Thesea Duchassaing \& Michellotti, and transferred to the family Plexauridae from the family Paramuriceidae. So far as I examined on specimens or in the literature, the coenenchyma of Filigella seems to be not so thick and two-layered as in most plexaurids, and the anthocodial armature is more powerful so as to form the operculum typical of paramuriceids. So it seems better to retain the genus name under the Paramuriceidae than to unite with the plexaurid Thesea.

\section{Family Plexauridae GRAY}

\section{Euplexaura attenuata (NUTTING), 1910}

(Fig. $11 ; \mathrm{Pl} . \mathrm{IX}$, fig. 12)

Plexaura attenuata NutTing, 1910b, p. 5, pl. 1, figs. 2-2a, pl. 1, figs. 2-2a, pl. 4, fig. 2.

Euplexaura attenuata KüKenthaL, 1924, p. 100 ; STIASNy, 1935, p. 13, textfig. B, pl. 1, fig. 2 ; UTINOMI \& HARADA, 1958, p. 388 (listed only).

Material. 1) One large syecimen, $55 \mathrm{~cm}$ long, with 2 branches arising perpendicularly. Tanabe Bay, probably $20-30 \mathrm{~m}$ (obtained by a lobster-net). 18-I-

1) Very recently I have had an opportunity to examine the type specimens of Filigorgia saharensis and $F$. ridouroi from West Africa (STIASNY, 1939) through the courtesies of Drs. VERSEVELDT, VerVOORT and STOCK. On examination I have recognized Filigorgia as a valid genus of the Paramuriceidae related to Filigella, and the latter species as a synonym of the former type species, $F$. saharenss, having only a slight difference in size of spicules. In both species, the coenenchyma is yellow or dirty white, while the biserially arranged anthocodiae are beautifully purple. 
1955. T. Yамамото coll.

2) 4 specimens. Southwest of Minabe, $80-150 \mathrm{~m} .28$ XI-1957. E. HARAdA coll.

3) One specimen, $27 \mathrm{~cm}$ long, with a bifurcate branch. Off Nada near Gobô City (obtained by a lobster-net). 28-V-1958. T. YAMAMOTo coll.

Description. The colonies of this plexaurid are all straight, simple or scantily branched. The second materials are all young form, attached to gastropod shells. They vary from $20 \mathrm{~cm}$ to $55 \mathrm{~cm}$ in height and from $1.2 \mathrm{~mm}$ to $2.8 \mathrm{~mm}$ in diameter. The largest one of the first material (dried when examind) shows only a narrow dark brown axis, and its diameter is $2.5 \mathrm{~mm}$ basally and terminates to $2 \mathrm{~mm}$.

The coenenchyma is dirty white in alcohol, but when living brown. The calicles are evenly distributed on all sides, about $1.5 \mathrm{~mm}$ apart. They are hardly raised above the general level of the coenenchyma, and almost all polyps are partially extended.

The calicular orifice distributed on the narrower distal part of the stem is, when viewed from above, semewhat lengthened along the axis, oval in outline, about $1 \mathrm{~mm}$ in longest diameter and one-half in shortest diameter. The polyps are completely retractile and deeply sink almost to the horny axis.

The coenenchymal spicules are all colorless, small spindles with multituberculate warts symmetrically arranged usually in 4 girdles. They measure in $\mathrm{mm}$ as follows :

$$
0.1 \times 0.017,0.14 \times 0.017,0.16 \times 0.07
$$

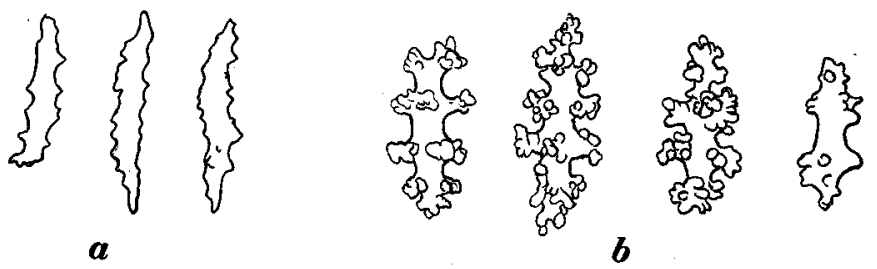

Fig. 11. Euplexaura attenuata (NUTTING).

$a$, Anthocodial spicules; $b$, coenenchymal spicules. $[a-b, \times 150$.

The anthocodial spicules are all colorless, slightly thorny spindles, as measuring in $\mathrm{mm}$ :

$$
0.1 \times 0.07,0.14 \times 0.017,0.16 \times 0.02
$$

Records of occurrence. Malay Archipelago (Nutring, Stiasny) ; Amoy, China (STIASNy). About $20-200 \mathrm{~m}$ in depth.

Family Chrysogorgiidae VERRILL

16. Chrysogorgia rotunda KINosHITA, 1913

(Fig. 12) 
Chrysogorgia rotunda KINOSHITA, 1913, p. 11, textfigs. 6-8, pl. 2, fig. 2 ; KưKENTHAL, 1924, p. 390, fig. 190 .

Material. One complete colony. Off Minabe, depth unrecorded. 1938.

Description. The present specimen is larger than the type specimen $(11.5 \mathrm{~cm}$ long, $7.5 \mathrm{~cm}$ wide) described and figured by Kinoshita (1913). It is attached to a stone by a flat, expanded, white calcareous basal disk, $5 \mathrm{~cm}$ across. Its total height is $14.5 \mathrm{~cm}$ and the cylindrical polyparium is about $8 \mathrm{~cm}$ in spread.

The stem gives off successive spirals of branches at short intervals (about $5 \mathrm{~mm}$ below and higher up). For a distance of about $4 \mathrm{~cm}$ on the lowest portion, the branches are broken off where the stem is about $3 \mathrm{~mm}$ in diameter. In the

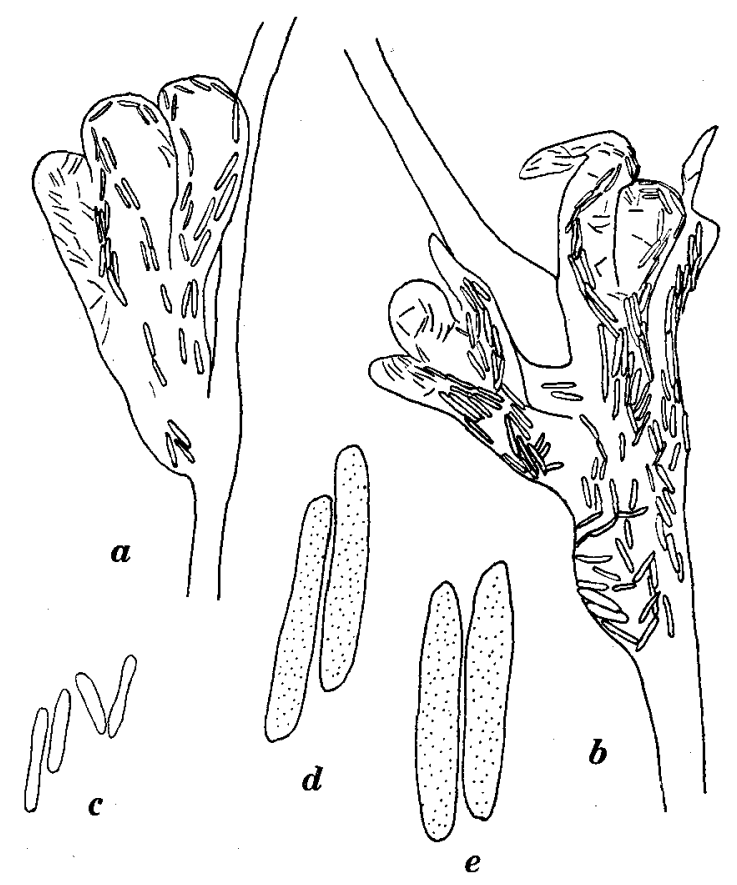

Fig. 12. Chrysogorgia rotunda KinoshiTA.

$a-b$, Polyps ; $c$, pinnule spicules; $d$, tentacle spicules ; $e$, polyp body spicules.

$[a-b, \times 33 ; c-e, \times 150$.

upper portion, the branches subdivide dichotomously many times, each almost in a horizontal plane, so that the colony forms a cylindrical shape.

The polyps occur on branches at intervals of about $2-3 \mathrm{~mm}$ on terminal twigs. They are all small, about $1 \mathrm{~mm}$ long and $0.3-0.5 \mathrm{~mm}$ wide.

Polypal body spicules are elongate flattened rods with a granular surface, about $0.18-0.5 \mathrm{~mm}$ long and $0.02 \mathrm{~mm}$ wide. Tentacle spicules are similar in shape, and longitudinally disposed on the dorsal side, about $0.1-0.18 \mathrm{~mm}$ long and 0.02 
$0.05 \mathrm{~mm}$ wide. Pinnnle spicules are tiny rodlets, about $0.035 \mathrm{~mm}$ long.

The coenenchyma is very thin, easily rubbed off and devoid of spicules and nematozooids. The axis is straw yellow, showing golden iridescence, while the polyps wholly white.

Record of occurrence. Hitherto known only from the type locality (Sagami Bay, down to 400 fms.)

\section{Family Primnoidae GraY}

\section{Plumarella cristata KüKENTHAL \& GORZAWSKY, 1908}

(Fig. 13; Pl. IX, fig. 13)

Plumarella cristata KÜKENTHAL \& GoRZAwSKY, 1908, p. 16, textfigs. 14-17, pl. 1, fig. 1 ; KỨKENTHAL, 1924, p. 258, fig. 147; Aurivillius, 1931, p. 241, textfig. 47 (1).

Plumarella carinata Kinoshita, 1908a, p. 17, textfig. 3 , pl. 1, fig. 8 and pl. 5, flg. 41 ; KinoshitA, 1908 b, p. 523, textfig. 6 , pl. 17, fig. 4 ; NutTING, 1912, p. 64.

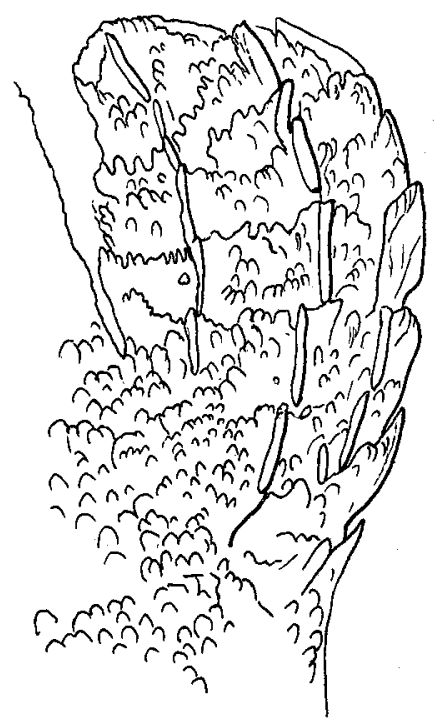

Fig. 13. Plumarella cristata KÜKENTHAL \& GORZAWSKY.

Polyp in side view. $[\times 80$.

Material. Two specimens, missing the base, $8 \mathrm{~cm}$ long and $12 \mathrm{~cm}$ long respectively. III-1950. M. Ozaki coll.

Records of occurrence. Sagami Bay, 80-600 m (Kükenthal \& Gorzawsky; Aurivillius) ; Kozu Island; south of Izu Peninsula (KInoshita); Osezaki, Suruga Bay, 95-106 fms. (Nutting). 


\section{Plumarella serta KÜKENTHAL \& GoRZAWSKY, 1908}

(Fig. 14; PI. IX, fig. 14)

Plumarella serta KüKENTHAL \& GoRZAwSKY, 1908, p. 14, textfigs. 11-13, pl. 1, fig. 4 ; KÜKENTHAL, 1924, p. 259.

Material. Three fragments. Off Minabe, $100-200 \mathrm{~m}$. III-1844. S. SAKAGUCHI coll.

Description. Three terminal branches here examined are as usual pinnately branched in one plane, at intervals of about $5 \mathrm{~mm}$. Their stem is about $1.2-1.5 \mathrm{~mm}$ in diameter and the side branches are about $0.18 \mathrm{~mm}$ in diameter.

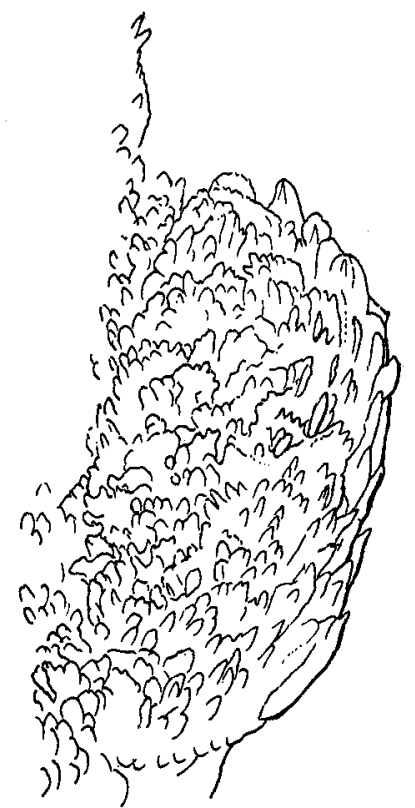

$\boldsymbol{\alpha}$

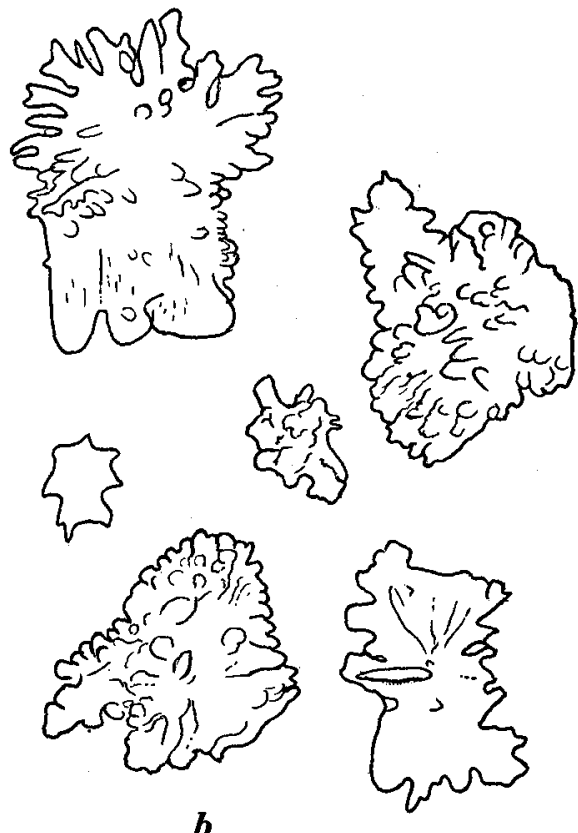

$\boldsymbol{b}$

Fig. 14. Plumarella serta KÜKenthal \& GoRZAWSKY.

$a$, Polyp in side view; $b$, thorny scales from polypal body wall. $[a, \times 80 ; b, \times 150$.

The polyps are regularly distributed on each side and usually crowded in parts. They are small, stout, club-shaped, usually $0.9-1.5 \mathrm{~mm}$ in height and $0.3 \mathrm{~mm}$ wide.

Polypal body spicules are closely warted, often nearly smooth, scales with strongly jagged margins. There are often dorsal cristae, which are not so distinct as in the preceding cristata. They measure in $\mathrm{mm}$ as follows :

$0.09 \times 0.018,0.1 \times 0.07,0.1 \times 0.018,0.18 \times 0.12,0.25 \times 0.18,0.3 \times 0.2$

Record of occurrence. Hitherto known only from the type localty (Sagami Bay, 80-250 m). 


\section{Thouarella hilgendorfi (STUDER), 1878}

Plumarella hilgendorfi STUDER, 1878, p. 648, p1. 2, fig. 15.

Thouarella hilgendorfi WRIGHT \& STUDER, 1889, p. 62, pl. 21, fig. 4; VeRSLUYs, 1906, p. 24, pl. 1, fig. 4 and pl. 2, fig. 7; Kinoshita, 1908a, p. 21, pl. 5, fig. 42; Nutring, 1912, p. 66 ; KüKentihal, 1924, p. 293 ; Aurivillius, 1931, p. 248, textfig. 48, pl. 5, fig. 8.

Material. Three specimens, 8-11 cm long. Off Minabe, 100-200 m. III-1944. SaKaguchi coll.

Records of occurrence. Widely distributed in Malayan waters and Japan such as Jeddobay (= Tokyo Bay) (type locality), Sagami Bay, Suruga Bay and west of Kyusyu, $100-2200 \mathrm{~m}$.

\section{PENNATULACEA \\ Suborder SESSILIFLORAE \\ Familly Veretilidae HERKLOTS}

20. Cavernularia obesa Milne EDwARDS \& HAIME, 1857

For description and synonyms see Kükenthal \& BROCH, 1911, p. 181.

Material. One specimen, $15 \mathrm{~cm}$ long, contracted. Off Minabe. III-1950.

Records of occurrence. Indian Ocean, Malay Archipelago, Australia and Japan, usually in shallow seas.

\section{Family Echinoptilidae HUBRECHT}

\section{Echinoptilum macintoshi HUBRECHT, 1885}

Echinoptilum macintoshi HuBRECHT, 1885, p. 512, 2 pls.; BALSs, 1910, p. 38, pl. 2, figs. 1-3 and pl. 5, figs. 3-5; NutTing, 1912, p. 48; THOMSON \& RENNET, 1927, p. 121, pl. 9, fig. F ; UTINOMI \& HARADA, 1958, p. 388 (listed only).

Material. 1) 2 specimens. $23 \mathrm{~km}$ west of Setozaki, $80-150 \mathrm{~m} .28-\mathrm{XI}-1957 . \mathrm{E}$. HARADA coll.

2) One specimen. 8 miles southwest of Kirimezaki, $150 \mathrm{~m} .16-\mathrm{XII}-1957 . \mathrm{M}$. Ozaki coll.

Records of occurrence. Hitherto known commonly from deep water of Japan; for example Kumanonada, $34^{\circ} 11^{\prime} \mathrm{N}, 136^{\circ} \mathrm{E}, 130 \mathrm{~m}$ (type locality), Sagami Bay, (Balss; Thomson \& Rennet), Dôgo Island, Zapan Sea (Nutring), Prov, Rikuzen and Uraga Channel (Thomson \& Rennet). Fu'rther recorded irom Hawaiian waters (NutTing, (1908, p. 561). 


\section{Family Kophobelemnidae GRAY \\ 22. Sclerobelemnon burgeri (HERKLOTS), 1858}

For description and synonyms see Balss, 1910, p. 27 and HICrson, 1916, p. 77.

Material. One large specimen, $20 \mathrm{~cm}$ long and $1.5 \mathrm{~cm}$ wide. Off Tanabe Bay. III-1950.

Record of occurrence. Known from Japan and Indo-Malayan waters, in 150 $180 \mathrm{~m}$ in depth.

\section{Family Funiculinidae GrAY \\ 23. Funiculina quadrangularis (PALLAS), 1766}

For description and synonyms see KöLltKer, 1870, p. 191 and p. 590, and BALss, 1910, p. 33.

Material. One specimen, $47 \mathrm{~cm}$ long and $2.5 \mathrm{~cm}$ wide at base. $23 \mathrm{~km}$ west of Setozaki, 80-150 m. 28-XI-1957. E. HaradA coll.

Record of occurrence. Apparently cosmopolitan, 18-2600 m (BALss).

Family Stachyptilidae KöLLIKER

\section{Stachyptium dofleini BALss, 1909}

(PI. X, figs. 15-16)

Stachyptilum dofleini BALss, 1909, p. 427.

Stachyptilum superbum BALsS, 1910, p. 36 (not STUDER); KÜKENTHAL \& BROCH, 1911, p. 261, figs. 84-91 ; Thomson \& Rennet, 1927, p. 129, pl. 9, figs. B-C ; Kumano, 1947, p. 1551, fig. 4361 .

Stachyptilum dofleini KüKENTHAL, 1913, p. 262 (emend.).

Material. One specimen. Off Minabe. Depth unrecorded. III-1950.

Description. The specimen is represented by a single large colony, about $19 \mathrm{~cm}$ long, of which the polyparinm is about $12 \mathrm{~cm}$ long and the sterile stalk is about $7.5 \mathrm{~cm}$, thus the radio of length between the polyparium and stalk is roughly $1.6: 1$. The maximum width of the polyparium is about $4 \mathrm{~mm}$ and the diameter of the stalk is about $3 \mathrm{~mm}$ in its collapsed condition.

The polyperium is grayish, while the stalk is reddish brown, darker towards the lowest end.

The autozooids are arranged laterally in oblique rows, about 33 in total number, and at the same time $4-6$ on one oblique-transverse row, decreasing in number towards up and down. Each of the autozooid calicles in the middle portion is about $4 \mathrm{~mm}$ long and $0.7 \mathrm{~mm}$ wide, and armed with a number of needles on the outer side; the distal margin is less spinose, usually only one tooth some- 
what conspicuous on both sides, though never so spine-like as in the real St. superbum as figured by NuTTING (1908, pl. 87, fig. 9) and by KüKENTHAL (1913, pl. 8, fig. 9). The scale-like siphonozooids occur laterally on the rachis in trian. gular clusters, leaving a dorso-median streak free.

Records of occurrence. Hitherto known only from Japan, especially Sagami Bay, 90-150 m (Balss), 80-350 fms. (Thomson \& Rennet), littoral to $150 \mathrm{~m}$. (KüKenthal). According to Kumano (1947), younger specimens, about $10 \mathrm{~cm}$ long, occur abundantly on sandy mud basin in the depths of $3-75 \mathrm{~m}$ around the coast of the same bay.

Remarks. As emended by KüKenthal (1913), the relative length of the polyparium and stalk and the less spinose calicular margins may serve to separate the Japanese form from the type species St. superbum STuder (1894) endemic to the Pacific coast of the central and north America.

\section{Suborder SUBSELLIFLORAE}

Family Pennatulidae EHRENBERG

25. Leioptilus fimbriatus (HERKLOTS), 1858

(PI. X, figs. 17-18)

Pennatula fimbriata HeRklots, 1858, p. 18, pl. 3, fig. 3 and pl. 4, fig. 1.

Leioptilus fimbriata GRAY, 1860, p. 22.

Leioptilus fimbriatus GRAY, 1870b, p. 21.

Pennatula fimbriata KÖLLIKER, 1872, p. 137.

P. sulcata Kölliker, 1880 , p. 8, pl. 2, figs. 3-4.

P. fimbriata BALss, 1910 , p. 55, pl. 1, figs. 6 \& 11, pl. 4, fig. 3 ; KüKenthal \& Broch, 1911, p. 376, figs. 171-176; Hrckson, 1916, p. 184, textfig. 36; THOMson \& RENNET, 1927, p. 131 ; Kumano, 1947, p. 1548, fig. 4353.

Ptilosarcus brevicaulis Nutting, 1912, p. 26, pl. 4, figs. 3-3a (after Deichmann, 1941). Leioptilus fimbriatus DeICHMANN, 1941, p. 12 (footnote).

Material. 1) One specimen, Off Minabe. III-1950.

2) Two specimens. 4 miles southwest of Susami, 250-270 m. 19-IV-1957. M. Ozaki coll.

3) One specimen. 8 miles southwest of Kirimezaki, $150 \mathrm{~m}$. 16-XII-1958. M. Ozaki coll.

4) Five small specimens. Stations $1,2 \& 4,23 \mathrm{~km}$ west of Setozaki, 120-150 m. 8-XII-1957. E. HARADA coll.

5) One specimen. 10 miles sothwest of Minabe, $150 \mathrm{~m} .10-\mathrm{I}-1960 . \mathrm{M}$. OzakI coll.

Description. This well known pennatulid has often been described in detail by many earlier authors, so that further description of the structure may be unnecessary. But only given here are the measurements of some specimens for comparison. 


\begin{tabular}{|c|c|c|c|c|c|c|c|c|}
\hline \multirow[b]{2}{*}{ Total length (mm) } & \multirow[b]{2}{*}{45} & \multicolumn{3}{|c|}{ Mat. (4) } & \multicolumn{3}{|c|}{ Mat. (2) } & \multirow{2}{*}{$\overbrace{130}^{\text {Mat. (5) }}$} \\
\hline & & 57 & 60 & 70 & 80 & 64 & 65 & \\
\hline Length of rachis (mm) & 28 & 36 & 37 & 42 & 50 & 40 & 43 & 90 \\
\hline Length of stalk (mm) & 15 & 21 & 23 & 25 & 30 & 23 & 25 & 40 \\
\hline Width of rachis $(\mathrm{mm})$ & 14 & 20 & 17 & 30 & 25 & 17 & 17 & 38 \\
\hline Number of leaves & 17 & 15 & 18 & 26 & 20 & 20 & 20 & 29 \\
\hline $\begin{array}{l}\text { Length of dorsal } \\
\text { margin of leaf }(\mathrm{mm})\end{array}$ & 10 & 12 & 8 & 17 & 19 & 10 & 10 & 20 \\
\hline
\end{tabular}

Among these specimens, the largest one, $130 \mathrm{~mm}$ long, only shows a flat bare median streak on the ventral side of the rachis between the leaves, while in all the other smaller specimens, rangiug from 45 to $80 \mathrm{~mm}$ in total length, an open channel-like deep groove is formed continually from up to down on the ventral side, and without exceptions a couple of the anomuran crab Uroptychus scandens BENEDICT ${ }^{1)}$ reside commensally within the groove, as noticed by HICKson (1916, p. 185).

Records of occurrence ${ }^{2)}$. Japan, 190-730 m (BALSS, etc.) ; Philippines, 18-36 m (Kölliker) ; Kei Islands, 112-397 m (Hickson).

\section{Family Pteroeididae KöLLIKER \\ 26. Pteroeides breve KöLLIKER, 1872}

(PI. X, figs. 19-20)

Pteroeides breve KöLLIKER, 1872, p. 79, pl. 4, figs. 31-32.

Material. One specimen, Off Minade. Depth unrecorded. III-1950.

Description. This specimen, having a short rachis, about $4 \mathrm{~cm}$ long and a plump stalk, about $5.2 \mathrm{~cm}$ long and $2 \mathrm{~cm}$ wide, may be identified with a littleknown species Pteroeides breve KöLLIKER by its shortened tip slightly projecting at the base of terminal leaves. The stem is short but very thick, and the leaves, 18 on each side of the rachis, are directed almost laterally.

A larger leaf is elongate triangular, about $28 \mathrm{~mm}$ long and $14 \mathrm{~mm}$ wide, with a median siphonozooid plate and $10-12$ spicular rays marginally projecting. The colony in alcohol is uniformly flesh-colored.

Record of occurrence. Hitherto known only from the type locality (Bohol Island, Philippines, 6-10 fms,).

1) BALss (1913) later recorded this crab from Dr. DofLEIN's collection but did not mention as to its habitat whatever.

2) Pennatula fimbriata, as reported from the coral reef of Koror Island, Palau (UTINOMI, 1956a, p. 240), a photograph of which is further reproduced in my book (UTINomI, 1956b, pl. 10, fig. 5), is unexpectedly a mistaken identity, although it may also occur there. It should be corrected to Pteroeides lacazii var. spinosum KöLLIKER. 


\section{LITERATURE CITED}

Aurivillius, M. 1931. The gorgonarians from Dr. Sixten Bock's Expedition to Japan and Bonin Islands 1914. Kungl. Svenska Vet.-Akad. Handl., ser. 3, Bd. 9, no. 4, pp. 1-337, pls. 1-6.

Balss, H. 1909. Ueber Pennatuliden des Münchener Museums. Zool. Anz., Bd. 34, pp. 423-431. 1910. Japanische Pennatuliden. [Beiträge zur Naturgeschichte Ostasiens, herausgegeb. von Dr. F. Doflein.] Abh. math.-phys. KI. K. Bayer. Akad. Wiss., Suppl.-Bd. II, Abhandlg. 2. 106 pp., 6 Taf.

1913. Ostasiatische Decapoden I. Die Galatheiden und Paguriden. [Beiträge zur Naturgeschichte Ostasiens, herausgegeb. von Dr. F. Doflein.] Ibid., Suppl.-Bd. II, Abhandlg. 9. 85 pp., 2 Taf.

BAYER, F. M. 1952. Descriptions and redescriptions of the Hawaiian octocorals collected by the U. S. Fish Commission steamer "Albatross". (1. Alcyonacea, Stolonifera and Telestacea.) Pacific Sci., vol. 6 , no. 2 , pp. $126-136$.

1956. Octocorallia. In: Treatise on Invertebrate Paleontology, Part F. Coelentorata, pp. 166-231. New York.

1958. Les octocoralliaires plexaurides des côtes occidentales d'Amérique. Mém. Mus. Natl. Hist. Nat., n. sér. (A) Zool., tom. 16, fasc. 2, pp. 41-56, pls. 1-6.

1959a. A review of the gorgonacean genus Placogorgia Studer, with a description of Placogorgia tribuloides, a new species from the Straits of Florida. J. Wash. Acad. Sci., vol. 49 , no. 2 , pp. 54-61.

- 1959b. Octocorals from Surinam and the adjacent coasts of South America. Studies on the Fauna of Suriname and other Guyanas, vol. 3, pp. 1-43. Hague.

DANA, J. D. 1846. Zoophytes. U.S. (Wilkes) Exploring Expedition $\cdots$ vol. 7, vi 740 pp., 45 figs., atlas of $11 \mathrm{col}$. pls. Washington.

DeICHMANN ${ }^{*}$ E. 1941. Coelenterates collected on the Presidental Cruise of 1938. Smithsonian Misc. Coll., vol. 99, no. 10, pp. 1-17, pl. 1.

Germanos, N. K. 1897. Gorgonaceen von Ternate. Abh. Senckenberg. Naturf. Ges., Bd. 23, pp. 145-187, Taf. 9-12.

Gray, J. E. 1860. Revision of the family Pennatulidae, with descriptions of new species in the British Museum. Ann. Mag. Nat. Hist., ser. 3, vol. 5, pp. 20-25, pls. 3-4.

1868. Descriptions of some new genera and species of Alcyonoid corals in the British Museum. Ibid., ser. 4, vol. 2, pp. 441-445.

1870a. Notes on some new genera and species of Alcyonoid corals in the British Museum. Ibid., ser. 4, vol. 5, pp. 405-408,

1870b. Catalogue of sea-pens or Pennatulariidae in the collection of the British

Museum. Brit. Mus., London. 40 pp.

HEDlund, T. 1890. Einige Muriceiden der Gattungen Achanthogoria [sic], Paramuricea und Echinomuricea im Zoologischen Museum der Universitet Uppsala. Bihang till K. Svenska Vet.Akad. Handlingar, Bd. 16, no. 6, pp. 1-18, Taf. 1-3.

Herklots, J. A. 1858. Notices pour servir à l'étude polypiers nageurs ou Pennatulides. Amsterdam. 30 pp., 7 pls.

HICkson, S. J. 1903. The Alcyonaria of the Maldives. Part I. The genera Xenia, Telesto,... In : The Fauna and geography of the Maldive and Laccadive Archipelagoes, edited by Mr. Gardiner, vol. 2 , pt. 1 , pp. $473-512$, pls. $26-27$.

1905. The Alcyonaria of the Maldives. Part III, The families Muriceidae, Gorgonellidae, Melithodidae,... Ibid.,vol. 2, pt. 4, pp. 807-826, pl. 67.

1916. The Pennatulacea of the Siboga Expedition, with a general survey of the order. Siboga-Expeditie, mon. XIV (Livr, 77). Leiden. 265 pp., 10 pls. and 1 chart.

1921. On some Alcyonaria in the Cambridge Museum. Proc. Camb. Phil. Soc., vol. 20 , pt. 3 , pp. $266-373$. 
Hubrechr, A. A. W. 1885. On a new pennatulid from the Japanese sea. Proc. Zool. Soc. Lond., 1885, pp. $512-518$, pl. 30.

KinoshitA, K. 1908a. Primnoidae von Japan. J. Coll. Sci. Univ. Tokyo, vol. 23, art. 12, pp. 1-74, pls. 1-6.

1908b-09. On the gorgonid family Primnoidae. Dobutsugaku Zasshi (Zool. Mag. Tokyo), vol. 20, pp. 409-419, 453-459, pls. 17-18; vol. 21, pp. 1-10, pl. 1. [In Japanese.] 1909a. Telestidae von Japan. Annot. Zool. Japon., vol. 7, no. 2, pp. 113-123, pl. 3. 1909b. On some muriceid corals belonging to the genera Filigella and Acis. J. Coll. Sci. Imp. Univ. Tokyo, vol. 27, art. 7, pp. 1-16, pls. 1-2.

1910. Notiz uiber Telesto rosea. Annot. Zool. Japon., vol. 7, no. 3, pp. 209-211.

1913. Studien über einige Chrysogorgiiden Japans. J. Coll. Sci. Imp. Univ. Tokyo, vol. 33, art. 2, pp. 1-47, pls. 1-3.

KöLlIKER, A. [1869-] 1872. Anatomisch-systematische Beschreibung der Alcyonarien. Erste Abteiluug: Pennatuliden. Abhandl. Senckenberg Naturf. Ges., Bd. $7 \& 8$, pp. 1-458, Taf. 1-24.

1880. Report on the Pennatulidae. Rep. Sci. Res. Voyage of H.M.S. Challenger,

Zool., vol. 1, pt. 2. London. 41 pp., 11 pls.

KÜkenthaL, W. 1909. Japanische Gorgoniiden. II. Teil : Die Familien der Plexauriden, Chrysogorgiiden und Melitodiden. [Beiträge zur Naturgeschichte Ostasiens, herausgegeb. von Dr. F. Doflein.] Abhandl. math.-phys. Kl. K. Bayer. Akad. Wiss., Suppl.-Bd. I, Abhandlg. 5, pp. 1-78, Taf. 1-7.

1911. Alcyonarien von den Aru-und Kei-Inseln nach dem Sammlungen von Dr. H. Merton. [Ergebnisse e. zool. Forschungsreise von H. Merton.] Abhandl. Senckernerg. Ges. Naturf., Bd. 33, pp. 305-346, Taf. 19-23.

1913. Ueber die Alcyonarienfauna Californiens und ihre tiergeographischen Beziehungen. Zool. Jahrb. Syst., Bd. 35, Hft. 2, pp. 219-270, Taf. 7-8.

1924. Gorgonaria. In: Das Tierreich, Lief. 47 , xviii +478 pp. Berlin \& Leipzig.

Kükenthal, W. \& Broch, Hj. 1911. Pennatulacea. Wiss. Ergebn. deutsch. Tiefsee-Exped. "Valdivia", Bd. 13, Hft. 2, i-iv+113-576, Taf. 1-17. Jena.

KüKEnTHAL, W. \& GoRzawsky, H. 1908. Japanische Gorgoniiden. I Teil: Die Familien der Primnoiden, Gorgoniiden und Acanthogorgiiden. [Beiträge zur Naturgeschiche Ostasiens, herausgegeb. von Dr. F. Doflein.] Abhandl. math.-phys. Kl. K. Bayer. Akad. Wiss., Suppl.-Bd. II, Abhandlg. 3. pp. 1-71, Taf. 1-4.

Kumano, M. 1947. Pennatulacea. In : Illustrated Encyclopedia of the Fauna of Japan, revised edition, pp. 1548-1552, figs. 4353-4552. Hokuryukan, Tokyo. [In Japanese.]

LaACKmanN, H. 1909. Zur Kenntnis der Alcyonarien-Gattung Telesto. Zool. Jahrb. Suppl., Bd. 11, Hft. 1, pp. 41-104, Taf. 2-8.

Milne EdWARDS, H. \& HaIme, J. 1857. Histoire naturelle de coralliaires ou polypes proprement dits. I-III. xxxiv +560 pp., 633 pp., 560 pp., 36 pls. Paris.

Nutting, C. C. 1908. Descriptions of the Alcyonaria collected by the U.S. Bureau of Fisheries steamer Albatross in the vicinity of the Hawaiian Islands in 1902. Proc. U.S. Natl. Mus., vol. 34 , no. 1624 , pp. $543-601$, pls. $41-51$.

pls. $84-91$.

1909. Alcyonaria of the Californian coast. Ibid., vol. 35, no. 1658, pp. 681-727,

1910a. The Gorgonacea of the Siboga Expedition. III. The Muriceidae. SibogaExpeditie, mon. 13b (Livr. 47), pp. 1-108, pls. 1-22. Leiden.

1910b. Ditto. IV. The Plexauridae. Ibid., mon. $13 b_{1}$, (Livr. 48), pp. 1-20, pls. 1-4. Leiden.

1912. Descriptions of the Alcyonaria collected by the U.S. Fisheries steamer "Albatross", mainly in Japanese waters, during 1906. Proc. U.S. Natl. Mus., vol. 43, no. 1923, pp. 1-104, pls. 1-21.

StIASNy, G. 1935. The Gorgonacea of the Siboga-Expedition. Supplement I. Revision der Plexauridae. Siboga-Expeditie, mon. $13 b_{7}$ (Livr. 124), pp. 1-106, Taf. 1-7. Leiden. 
Stiasny, G, 1939. Gorgonaria von Kap Blanco, Senegal und Rio d'Ouro. Rev. Zool. Bot. Afr., vol. 32, fasc. 3-4, pp. 285-322, Taf. 10-18.

1942. Ergebnisse der Nachuntersuchung der Muriceidae (Gorgonaria) der SibogaExpedition. Vorläufige Mitteilung. Zool. Anz., Bd. 140, Hft. 9/10, pp. 191-199.

1947. De Gorgonarien-Familie Acanthogorgiidae Kükent. \& Gorz. (met Bijzondere in achtneming van het materiaal der Sibogo-Expeditie). Verh. Koninkl. Ned. Akad. Wet. Afd. Natuurkunde, Tweede sectie, D1. 43, no. 2, pp. 1-93, pls. 1-3.

STUder, Th. 1878. Übersicht der Anthozoa Alcyonaria, welche während der Reise S. M. S. Gazelle um die Erde gesammelt wurden. Monatsber. König. Preuss. Akad. Wiss. Berlin, Sept--Okt. 1878, pp. 632-688, Taf. 1-5.

1889. Supplementary report on the Alcyonaria collected by the H. M. S. Challenger during the years 1873-76. Rep. Sci. Res. Voyage Challenger, Zool., vol. 32, pt. 81, pp. 1-31, pls. 1-6. London.

1894. Note préliminaire sur les alcyonaires. Bull. Mus. Comp. Zoöl. Harvard Coll., vol. 25 , no. 5 , pp. 53-69.

Thomson, J. A. \& DeAN, L. M. I. 1931. The Alcyonacea of the Siboga-Expedition, with an addendum to the Gorgonacea. Siboga-Expeditie, mon. 13d (Livr. 115), pp. 1-227, pls. 1-28. Leiden.

Thomson, J. A. \& Henderson, W. D. 1905. Report on the Alcyonaria collected by Professor Herdman at Ceylon in 1902. Ceylon Pearl Oyster Fisheries-1905-Suppl. Rep., no. 20, pp. 269328 , pls. 1-6. London.

1906. An account of the alcyonarians collected by the Royal Indian Marine Survey ship "Investigator" in the Indian Ocean. I. The alcyonarians of the deep sea. $x v i+132$ pp., 10 pls. Calcutta.

Thomson, J. A. \& MACkinnon, D. L. 1911. The alcyonarians of the "Thetis" Expedition. Mem. Austr. Mus., vol. 4, pt. 13, pp. 661-695, pls. 41-82.

Thomson, J. A. \& Rennet, N. I. 1927. Report on Japanese pennatulids. J. Fac. Sci. Imp. Univ. Tokyo, Sect. IV, Zool., vol. 1, pt. 2, pp. 115-143, pls. 7-9.

Thomson, J. A. \& Stmpson, J. J. (a note by Henderson, W. D.) 1909. An account of the alcyonarians collected by the Royal Indian Marine Survey ship "Investigator" in the Indian Ocean. II. The alcyonarians of the littoral area. xviii +319 pp., 9 pls. Calcutta.

Utinomi, H. 1954. On a small collection of Anthozoa from the Inan coast, Ehime Prefecture. Mem. Ehime Univ., Sect. II, Ser. B (Biol.), vol. 2, no. 1, pp. 101-106.

1956a. On some alcyonarians from the West-Pacific islands (Palau, Ponape and Bonins). Publ. Seto Mar. Biol. Lab., vol. 5, no. 2, pp. 221-242.

1956b. Colored illustrations of sea shore animals of Japan. xviii +167 pp., $62+12$ pls. Hoikusha, Osaka. [In Japanese]

1958. On some octocorals from deep waters of Prov. Tosa, Sikoku. Publ. Seto Mar. Biol. Lab., vol. 7, no. 1, pp. 89-110, pls. 5-6.

- 1960. Noteworthy octocorals off the southwest coast of Kii Peninsula, middle Japan. Part 1, Stolonifera and Alcyonacea. Ibid., vol. 8, no. 1, pp. 1-26, pls. 1-2.

UTINOMI, H. \& HARADA, E. 1958. A list of bottom animals collected by a trawler "Kaiun-maru" off the southwest coast of Kii Peninsula. Ibid., vol. 6, no. 3, pp. 385-395.

VERRILL, A. E. 1865. Synopsis of polyps and corals of the North Pacific Exploring Expedition, ... from 1853 to 1856 . Collected by Dr. Wm. Stimpson, naturalist to the expedition, etc. Part II. Alcyonaria. Proc. Essex Inst., vol. 4, no. 10, pp. 181-19 6, pls. 5-6.

1868. Critical remarks on the halcyonoid polyps in the Museum of Yale College, with descriptions of new genera. Amer. J. Sci. and Arts, vol. 45, May, pp. 411-418.

pls. 1-2. 
Versluys, J. 1906. Die Gorgoniden der Siboga-Expedition. II. Die Primnoidae. Siboga-Expeditie, mon. 13a (Livr. 27), pp. 1-187, Taf. 1-10. Leiden.

Wright, E. P. \& Studer, Th. 1889. Report on the Alcyonaria collected by H. M. S. Challenger during the years 1873-1876. Rep. Sci. Res. Voyage Challenger, Zool., vol. 31, pt. 64, 1xxii+ 314 pp., 43 pls. London.

\section{EXPLANATION OF PLATES VII-X}

\section{Plate VII}

Fig. 1. Acalycigorgia inermis (HEDLUnd). $\times 1$

Fig. 2. Acanthogorgia japonica KüKenthal \& GoRZawsKy. $\quad \times 1$

Fig. 3. Muricella abnormalis NuTTING. $\times 5 / 3$

Fig. 4. Discogorgia dendritica (NuTting). $\times 4 / 5$

\section{Plate VIII}

Fig. 5. Muricella nitida (VERRILL), $\times 1$

Fig. 6. Muricella magna n. sp. (Holotype) $\times 1$

Fig. 7. Distal part of the same, magnified. $\times 2$

Fig. 8. Astrogorgia rubra Thomson \& Henderson. $\quad \times 2$

Fig. 9. Menella indica GRAY. $\times 1$

\section{Plate IX}

Figs. 10-11. Filigella mitsukurii KINOSHITA. $\times 2 / 5$

Fig. 12. Euplexaura attenuata (NuTting), $\times 1 / 2$

Fig. 13. Plumarella cristata KüKENTHAL \& GoRZAwSKY. $\times 1$

Fig. 14. Plumarella serta KüKENTHAL \& GORZAWSKY. $\times 1 / 2$

\section{Plate X}

Fig. 15. Stachyptilum dofeini BALss. $\times 3 / 5$

Fig. 16. Part of rachis of the same, magnified. $\times 3$

Fig. 17. Leipterus fimbriatus (HERKLOTs), dorsal side. $\times 1$

Fig. 18. The same with a median groove, ventral side. $\times 1$

Fig. 19. Pteroeides breve Kölliker, dorsal side. $\times 2 / 3$

Fig. 20. The same, ventral side. $\times 2 / 3$ 


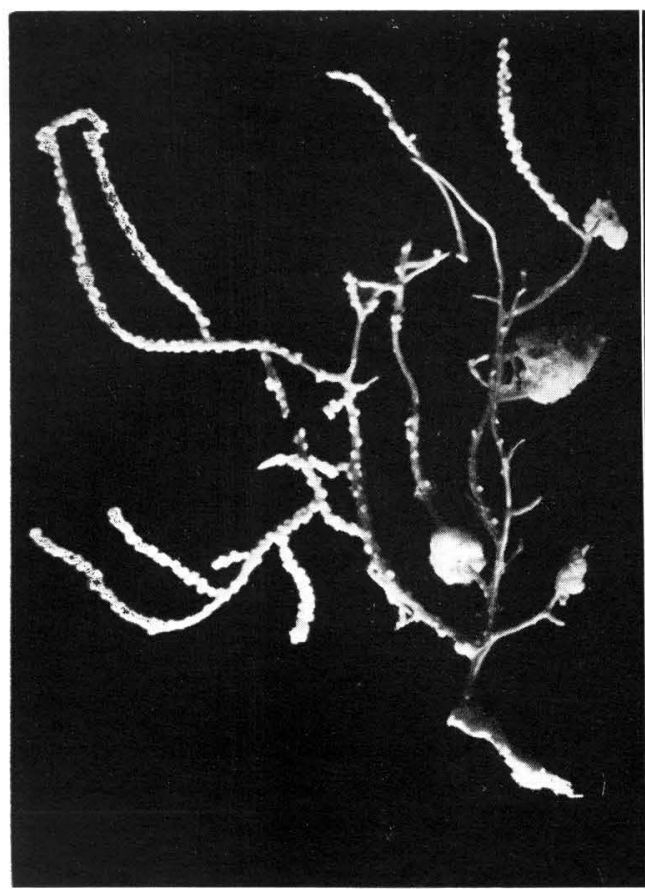

1

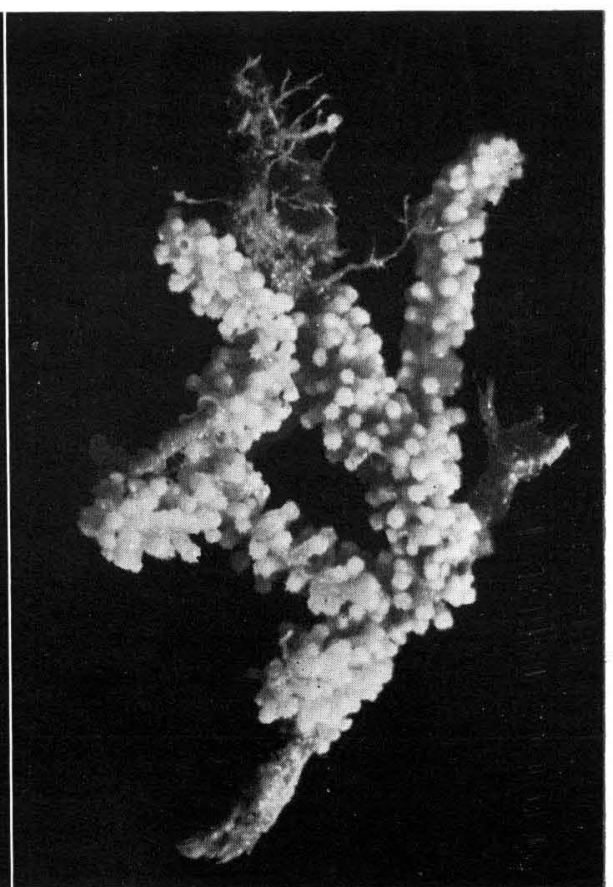

2

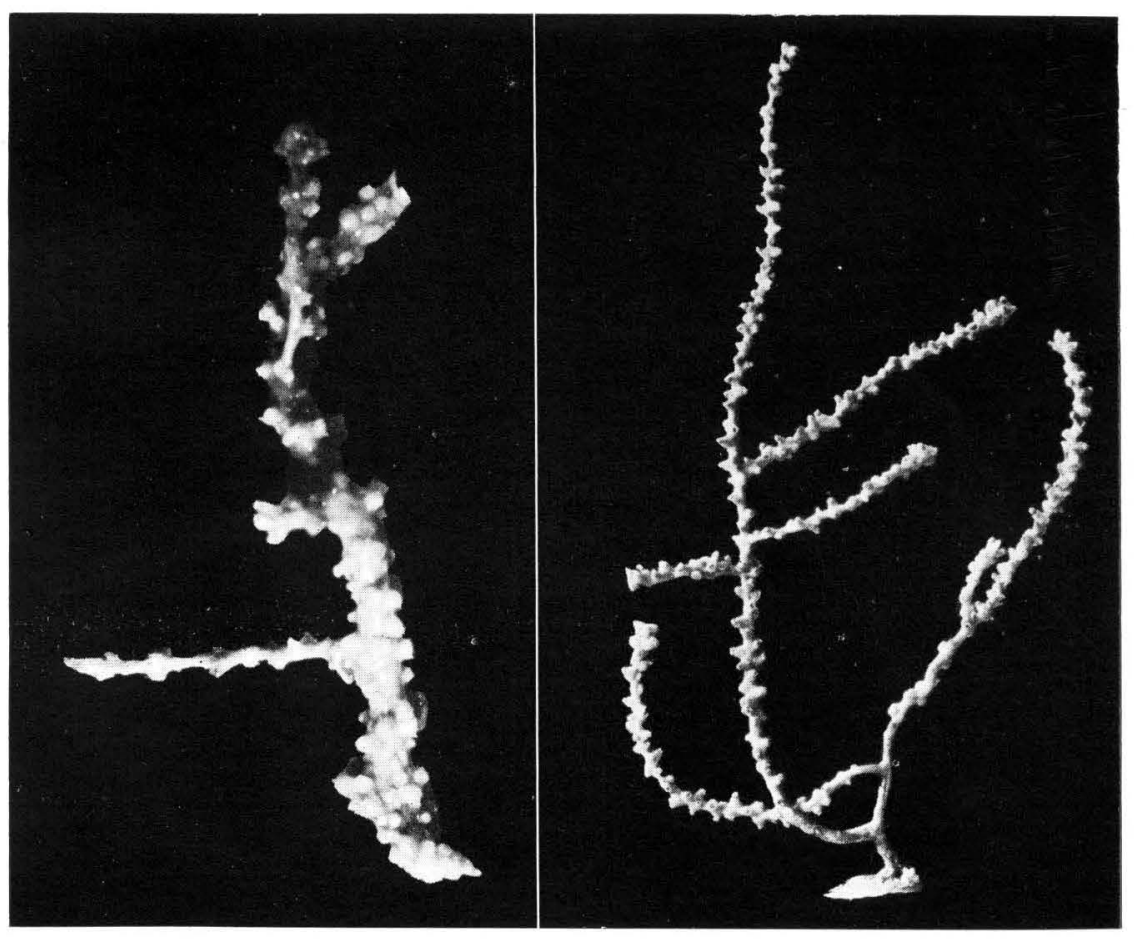

$s$

4

H. Utinomi: Noteworthy Octocorals Collected off Kin Peninsula, 2. 

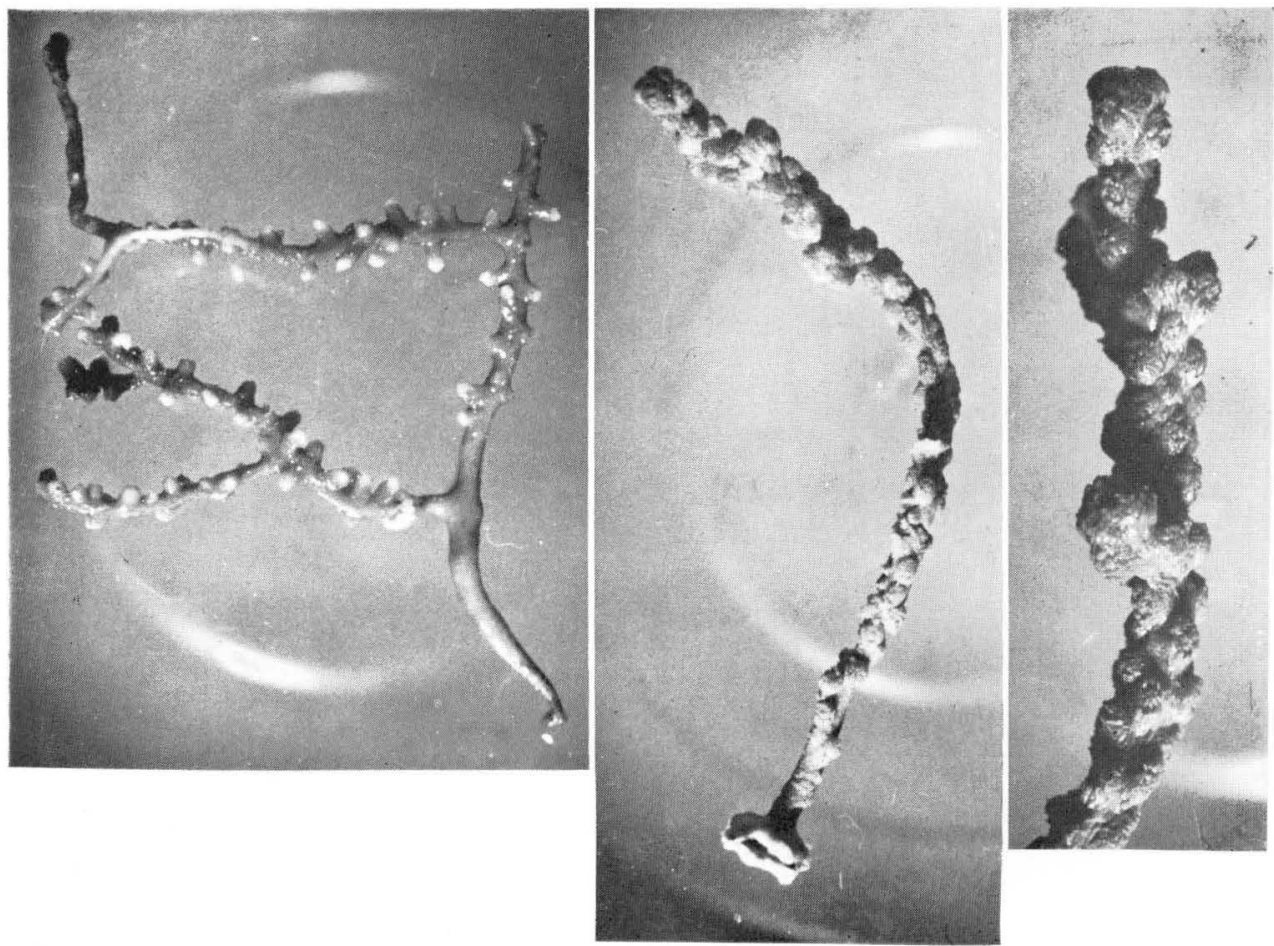

5

6

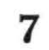

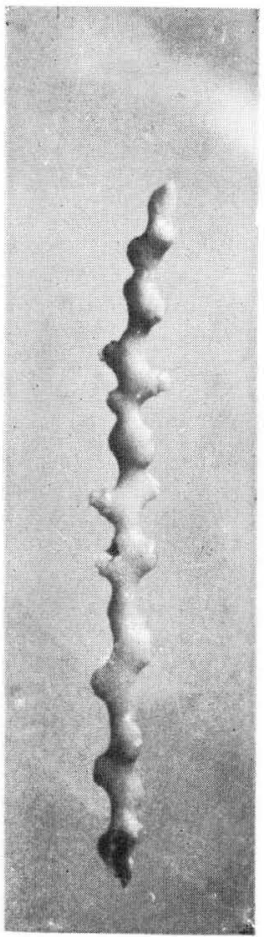

8

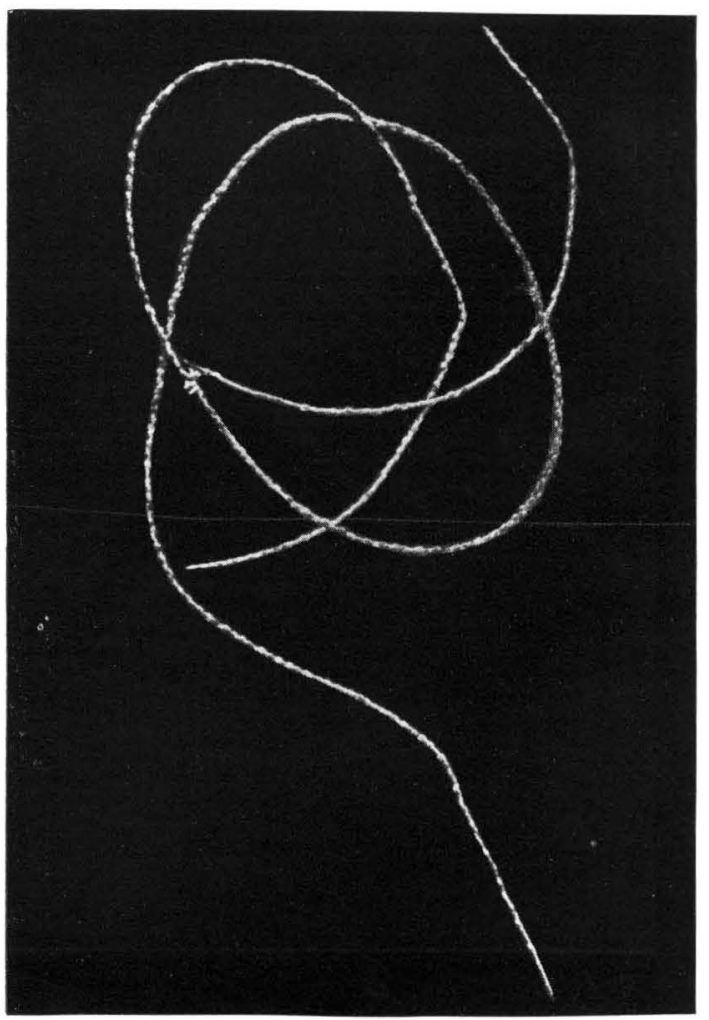

9

H. Utinomi: Noteworthy Octocorals Collected off Kin Peninsula, 2. 


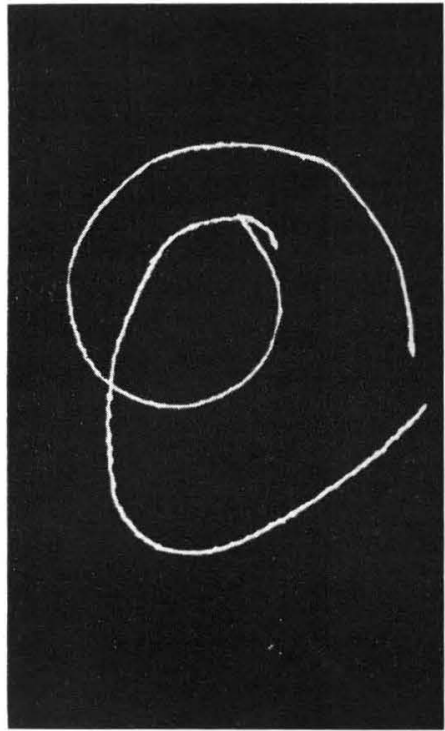

10

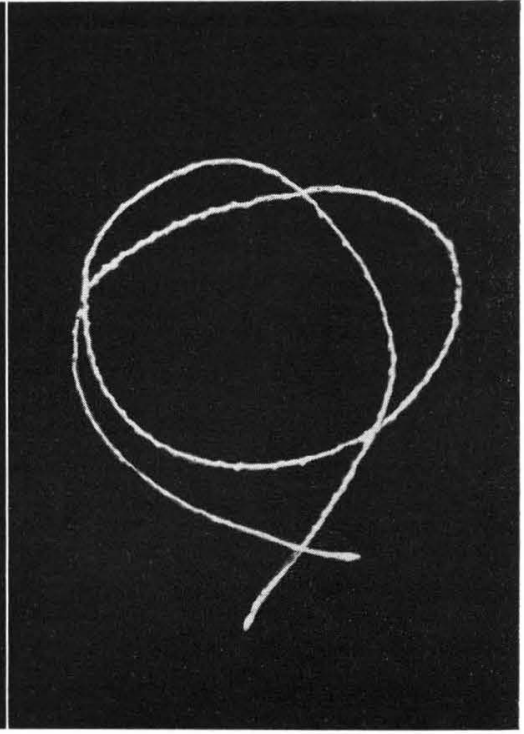

11

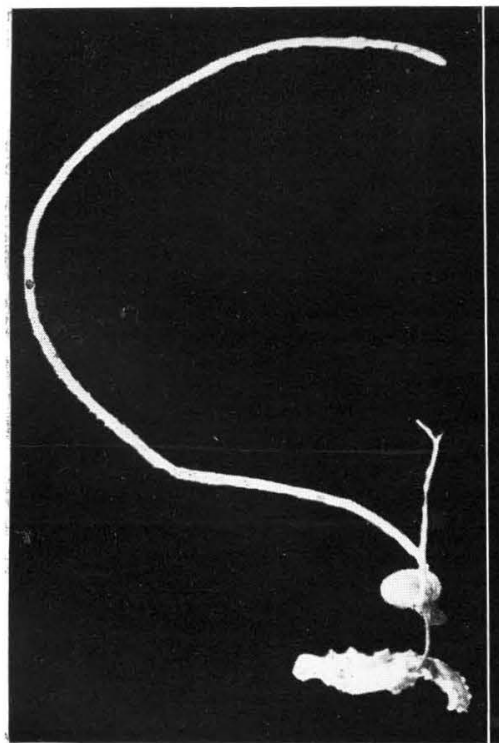

12

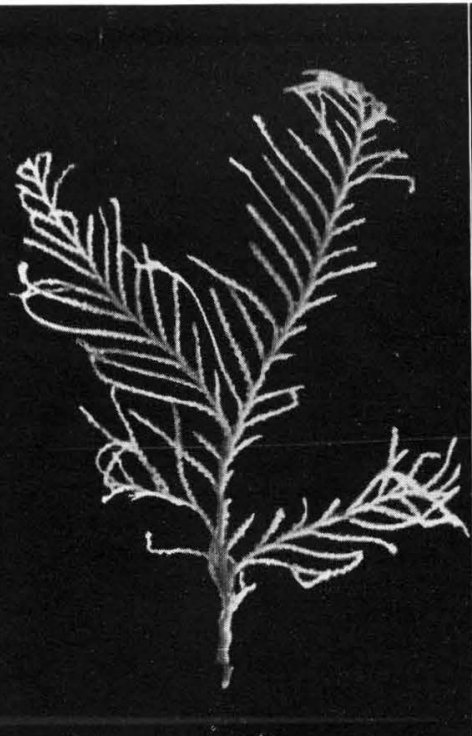

13

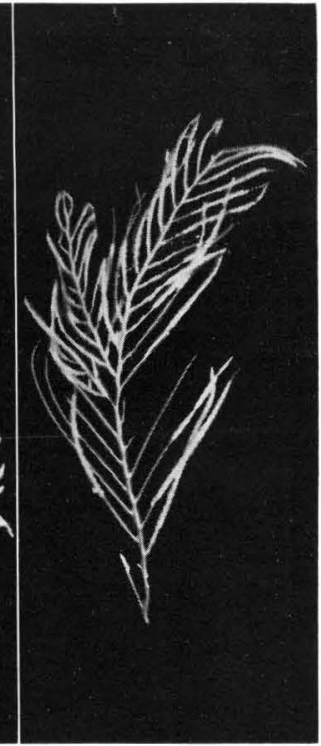

14

H. Utinomi: Noteworthy Octocorals Collected off Kif Peninsula, 2. 


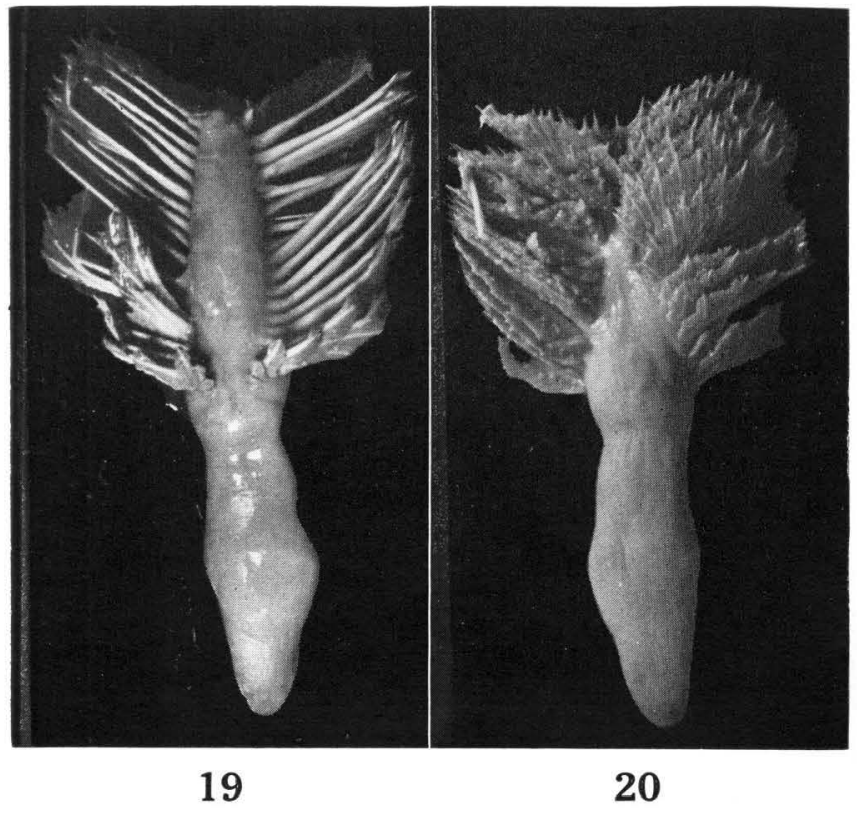

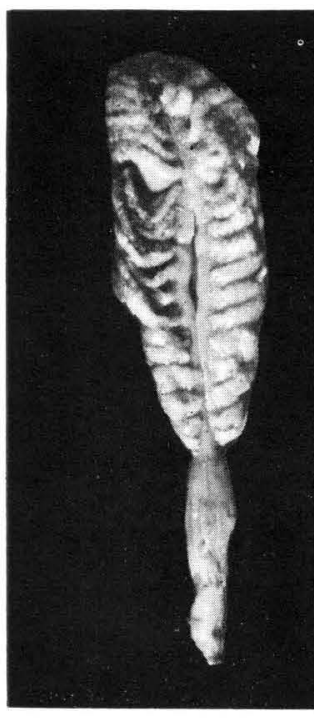

18

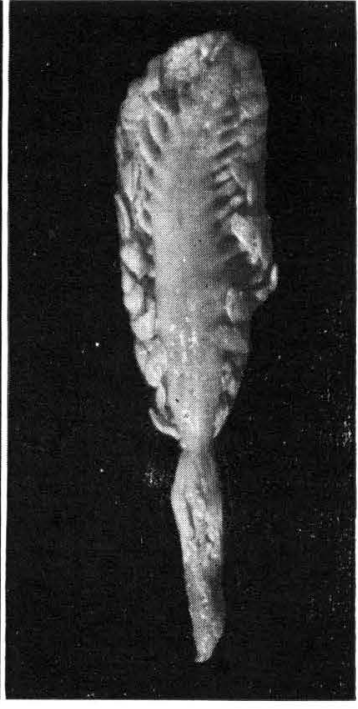

17

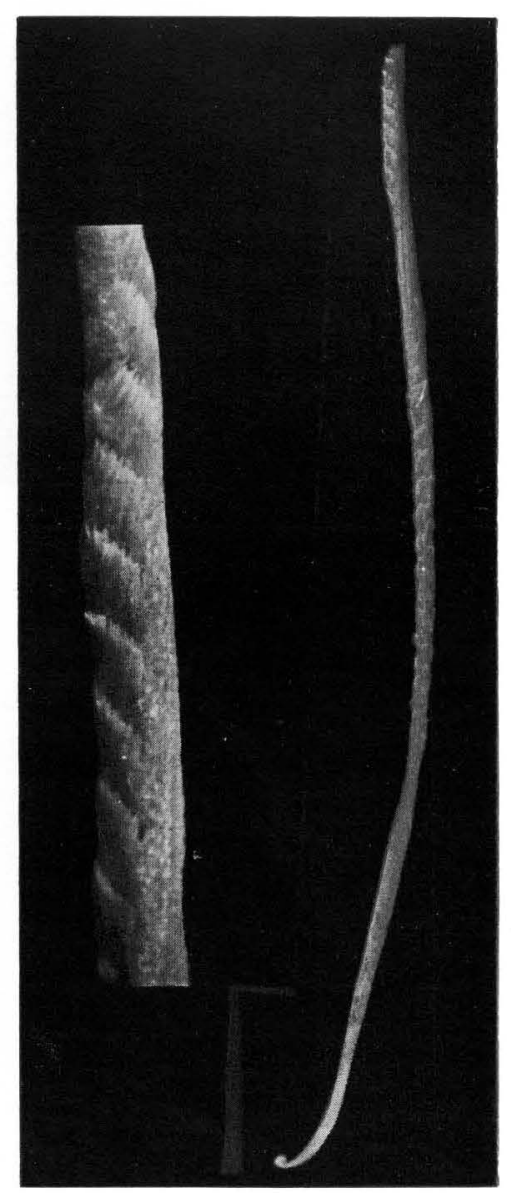

16

H. Utinomi: Noteworthy Octocorals Collected off Kin Peninsula, 2. 